\title{
Alternative energy - prospects for Sri Lanka
}

\author{
Janaka Ratnasiri \\ 27, Sudarshana Mawatha, Nawala, Rajagiriya.
}

\begin{abstract}
During the last decade many countries have taken policy decisions to use non-fossil fuels for both heat and electricity generation, and by 2005 , have achieved global shares of $10 \%$ and $2 \%$ respectively, in the two sectors. European countries have taken the lead in investing on renewable energy resources such as biomass and wind energy systems as well as adopting bio-fuels in transport. The climate change concerns of avoiding fossil fuel burning have resulted in additional funding being channelled to developing countries including Sri Lanka for undertaking alternative energy projects, where a $4 \%$ share of alternative sources has been achieved in the electricity sector. Studies carried out in Sri Lanka have shown that a short coppice crop, Gliricidia sepium, is suitable for planting in underutilized land estimated at 1.0 - 1.6 Mha for extracting biomass for use in thermal energy and dendro power generation. It is suggested that a new crop - sweet sorghum - be promoted for generating thermal energy as well as manufacturing bioethanol and to promote Jatropha circus for producing biodiesel. Estimates made with new land allocated equally among Gliricidia, sweet sorghum and Jatropha, and using other marginal land show that Sri Lanka has the potential to become self-sufficient in energy in the medium term, except in the replacement of diesel where only a $20 \%$ share could be achieved. A significant contribution for meeting domestic energy needs particularly in rural areas could be obtained from biogas digesters fed with the waste from over 1.5 million cattle. It is also found that if the new technology of synthesising methanol and dimethyl either from carbon monoxide and hydrogen present in syngas is adopted, gasified biomass could produce fuel which could be used in the transport sector and in domestic and commercial cooking and heating, replacing all imported fuel, including diesel. In order to ensure energy security in all sectors, efforts should be attempted to exploit the inexhaustible resources such as solar and wind energy available freely within the country, especially to meet individual requirements. Sri Lanka should also have a long term strategy to utilize these resources to generate hydrogen to take advantage of the upcoming fuel cell technology in the near future.
\end{abstract}

Keywords: Alternative energy, biomass, renewable energy, solar energy, wind energy.

\section{INTRODUCTION}

Energy is considered to be a basic human need, not only for mere survival but also for leading a life with comfort and enjoying the benefits of today's technology. Before fossil fuels were discovered, man depended on biomass collected from his surroundings to make fire to cook and keep him warm during cold days, and on vegetable oil for lighting. After the industrial revolution in the $18^{\text {th }}$ and $19^{\text {th }}$ centuries, coal was used widely as a source of energy for heating, lighting and railway transportation. With the development of the alternator in the late $19^{\text {th }}$ century, use of coal was extended to drive steam turbines to provide motive power for generating electricity, which is continued to date in many countries.

The availability of energy sources which are affordable, convenient and adequately safe has made it possible for the man to extend his mobility, manufacture goods, provide services, communicate with each other at distance and modify his built environment leading to a better quality of life than what his predecessors led. Countries which exploited these resources readily found themselves in a higher stratum of economy than others. One characteristic of the fossil fuels is their limited reserves. Their production, particularly in the case of petroleum oil, has now reached a peak, and what is expected in the future is a decline in the reserves and an escalation of the prices ${ }^{1}$. This is so even with the other fuels. In the recent past, prices of all three fossil fuel - crude oil, coal and natural gas - have shown an 
unprecedented increase and it is likely that the prices will increase further in the short term, straining the economies of fossil fuel dependent countries.

It is unimaginable to see one day a few decades hence, all petroleum driven vehicles and industries brought to a halt for want of fuel. Hence, attention of nations has now been directed to explore various other options available to avoid such a calamity. One option would be to shift for alternative energy sources (AES). Another option would be to develop techniques that would extract hitherto unutilised sources of fossil fuels in a cost effective manner. There is a third option available; that is to extend the life of conventional reserves through energy conservation. In this paper, emphasis will be given to a discussion on the first option.

\section{Alternative energy consumption - global}

The present day energy sources fall into three broad categories:
a. Exhaustibles : fossil fuels and nuclear fuels
b. Inexhaustibles : solar power, wind power,
oceanic power
c. Renewables : biomass, biofuels and hydropower

Fossil and nuclear fuels could best be described as exhaustible energy sources as one day these deposits will get exhausted. Inexhaustible energy sources (IES) are those that would be present as long as the Earth system exists, such as solar radiation, winds, ocean currents, tides and ocean temperature driven systems, while renewable energy sources (RES) are those that need to be renewed regularly such as biomass, biofuels (by planting and harvesting of crops) and hydro power (by precipitation). These are not available continuously unlike IES. All IES are alternatives to conventional systems while in RES, only efficient biomass utilization and small hydropower fall under AES. Also, RES include conventional sources such as traditional biomass utilization and large hydro plants, and these are excluded from alternative sources. AES are also referred to as non-conventional renewable energy (NCRE) sources.

In view of the important role AES could play in the development of a country, the UN Commission on Sustainable Development (UNCSD) has adopted a renewable energy related indicator that shows renewable energy share in national energy and electricity statistics ${ }^{2}$. Table 1 gives the breakdown of the total primary energy supply (TPES) and the global electricity consumption for 2005. The ratio of AES to TPES globally has been $10 \%$, while for electricity generation it has been only $2.2 \%$. This is because sources such as fuel wood, agriculture residue and solar thermal collectors, mostly have applications in heat generation rather than in electricity generation.

Table 1: Total primary energy supply and electricity generation in $2005^{3}$

\begin{tabular}{lrrrr}
\hline \multirow{2}{*}{ Fuel } & \multicolumn{2}{c}{$\begin{array}{r}\text { Primary Energy } \\
\text { Supply }\end{array}$} & \multicolumn{2}{c}{$\begin{array}{c}\text { Total Electricity } \\
\text { Consumption }\end{array}$} \\
\cline { 2 - 5 } & \multicolumn{1}{c}{ PJ } & $\%$ & TWh & $\%$ \\
\hline Coal & 121,611 & 25.4 & 7,349 & 40.3 \\
Oil & 168,053 & 35.1 & 1,204 & 6.6 \\
Gas & 99,587 & 20.8 & 3,592 & 19.7 \\
Hydro & 11,012 & 2.3 & 2,918 & 16.0 \\
Nuclear & 30,642 & 6.4 & 2,772 & 15.2 \\
Alternatives & 47,878 & 10.0 & 401 & 2.2 \\
\hline Total & 478,783 & 100 & 18,235 & 100 \\
\hline
\end{tabular}

The distribution of electricity generation from AES including geothermal, solar, wind, wood and waste among different regions in the world is shown in Table 2 for 1995 and 2005. While in 1995 North America generated the highest amount of electricity from AES, in 2005 this position was taken over by Europe which demonstrated over $310 \%$ growth in electricity generation from AES. Globally too, there had been over $110 \%$ growth in AES generated electricity.

Table 2: Electricity generation from alternative sources in 1995 and $2005^{4}$

\begin{tabular}{lrrr}
\hline \multicolumn{1}{c}{ Region } & \multicolumn{2}{c}{ TWh } & \% Growth \\
\cline { 2 - 3 } & 1995 & 2005 & \\
\hline N. America & 88.80 & 119.17 & 34.2 \\
S. \& C. America & 11.28 & 26.00 & 130.5 \\
Europe & 38.94 & 160.11 & 311.2 \\
Eurasia & 1.54 & 3.12 & 102.6 \\
M. East & 0.00 & 0.01 & \\
Africa & 0.43 & 1.96 & 355.8 \\
Asia & 27.85 & 52.59 & 88.8 \\
Oceania & 3.40 & 6.75 & 98.5 \\
\hline World & 172.24 & 369.71 & 114.6 \\
\hline
\end{tabular}

The contributions from AES for electricity and heat generation by major players in the world in 2006 are shown in Table 3. For electricity, the largest contribution of $74 \mathrm{GW}$ comes from wind energy (WE) plants, followed by small hydro (SH) plants contributing 73 $\mathrm{GW}$, and biomass (BM) plants contributing $45 \mathrm{GW}$. EU is in the forefront $(75 \mathrm{GW})$, followed by China $(52 \mathrm{GW})$ and USA (26 GW). Biomass contribution for thermal energy generation is 5 times more than that for electricity generation, while for solar this ratio is about 20 . 
Table 3: Electricity and heat generation capacity in GW using alternative sources - $2006^{5}$

\begin{tabular}{lrrrrrrr}
\hline Technology & \multirow{2}{*}{ World } & Dev* & EU-25 China & USA & India & Japan \\
\hline Electricity & & & & & & & \\
Wind Energy & 74 & 10 & 48.5 & 2.6 & 11.6 & 6.3 & 1.6 \\
Small Hydro & 73 & 51 & 12 & 47 & 3.0 & 1.9 & 3.5 \\
Biomass (E1.) & 45 & 22 & 10 & 2.0 & 7.6 & 1.5 & $>0.1$ \\
Geothermal & 9.5 & 4.7 & 0.8 & $\sim 0$ & 2.8 & $\sim 0$ & 0.5 \\
Solar PV** & 5.1 & $\mathrm{~ns}+$ & 3.2 & $\mathrm{~ns}$ & 0.3 & $\mathrm{~ns}$ & 1.5 \\
Solar CSP+ & 0.4 & $\mathrm{~ns}$ & $\mathrm{~ns}$ & $\mathrm{~ns}$ & 0.4 & $\mathrm{~ns}$ & $\mathrm{~ns}$ \\
Ocean tides & 0.3 & 0 & 0.3 & 0 & 0 & 0 & 0 \\
\hline Sub-Total & 207 & 88 & 75 & 52 & 26 & 10 & 7 \\
Thermal & & & & & & & \\
Biomass (Th) & 235 & & & & & & \\
Solar Thermal & 105 & & & & & & \\
\hline Total & 547 & & & & & & \\
\hline
\end{tabular}

* Dev= developing countries

** Only the grid-connected PV systems are included

+ ns: not significant; CSP: Concentrator solar plants

Among developing countries, China and India have taken the lead in investing on AES, with the latter dominating the scenario for WE plants $(6.3 \mathrm{GW})$. The capacity for heat generation from AES is about 1.7 times higher than that for electricity generation, with biomass contributing the major share. Here, only high efficient biomass systems are included rather than traditional systems. In solar thermal systems, China leads with 68 GW capacity and EU following with $13.5 \mathrm{GW}$ capacity.

Only an overview of the global AES scenario is given here. A detailed analysis will be given later under each technology sector.

\section{Implications of climate change}

The Kyoto Protocol (KP) ${ }^{6}$ of the UN Framework Convention of Climate Change (UNFCCC) requires developed countries and countries with economies in transition (EIT) (jointly referred to as Annex I Parties) to reduce their greenhouse gas (GHG) emissions by about 6\% below their 1990 levels during the 5-year period 2008-12. The 6\% average reduction relative to 1990 level of emissions that is specified in the KP gets magnified to about $15 \%$ when taken relative to the current levels of emissions. Many countries that have ratified the protocol, have failed to keep to their obligations, as shown in Figure 1. While almost all EIT countries have been able to reduce their emissions, among the nonEIT countries emissions have increased up to $10 \%$ by 2005. Hence, these countries are now under pressure to reduce their emissions, particularly after the 13th Conference of Parties (COP) of UNFCCC held at Bali in 2007 where an action plan was adopted committing all Parties to agree on a long-term goal for emission reductions with emission reduction targets applicable to developed country Parties beyond 2012 and nationally appropriate mitigation actions consistent with sustainable development applicable to developing country Parties negotiated during 2008-09 for consideration at the 15th COP to be held in $2009^{7}$. Hitherto, developing countries did not have any such obligation.

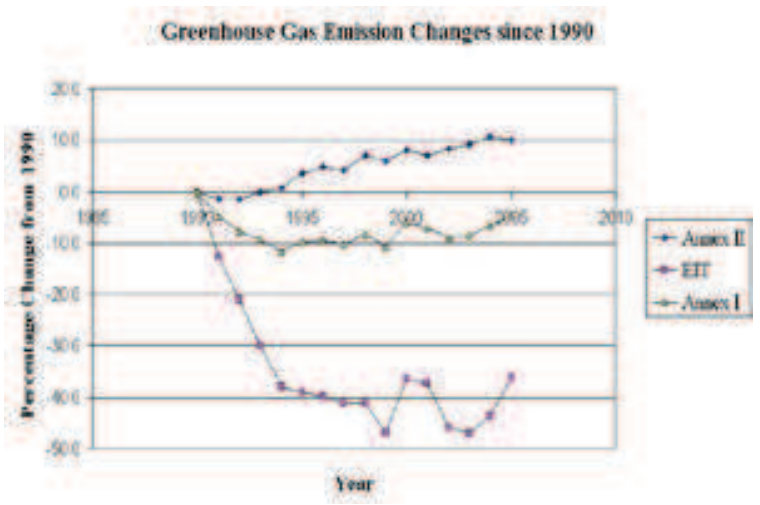

Figure 1 : GHG Emissions from Annex I countries during 1990 $2005^{8}$

The GHGs are emitted mostly by burning of fossil fuels for energy generation including transport. Thus, one of the most effective ways of reducing emissions is to use AES. Annex I countries are permitted to meet their obligations by not only reducing emissions within their own territories, but also meeting the costs of reducing emissions within a non-Annex I country. This mechanism, referred to as the Clean Development Mechanism (CDM), provides opportunities for developing countries to undertake GHG reducing or avoiding projects including energy efficiency and AES utilization, with the additional costs borne by Annex I countries 9 . Sri Lanka has already initiated action to seek CDM funding and has identified $19 \mathrm{CDM}$ projects by 2005 , which are in different stages of the design/validation process ${ }^{10}$.

In 1991, a financial mechanism called the Global Environment Facility (GEF) was established under the aegis of the World Bank (WB), United Nations Development Programme(UNDP) and the United Nations Environment Programme (UNEP) for the purpose of providing funds to developing countries for meeting their obligations under several environmental treaties including UNFCCC. A large number of programmes has been supported by GEF to implement AES projects that reduce or avoid GHG emissions in the areas of renewable energy, energy efficiency, and sustainable transport, particularly where the high initial costs involved makes the projects uneconomical when assessed using traditional economic 
criteria. In such instances, GEF provides funds to meet the additional costs involved to make the projects viable. In recent years, GEF has disbursed about $\$ 250$ million per year for eligible projects, including several from Sri Lanka ${ }^{11}$.

\section{Alternative energy programmes in Sri Lanka}

Sri Lanka's energy scenario already comprises a significant share of RES - almost 53\% - contributed by biomass and hydro power plants, both large and small. The detailed breakdown of contributions made by different fuel types in 2005 is shown in Table 4. Most of the data in original units are taken from the National Energy Information System (NEIS) 2005 . However, in converting electricity generated into a common energy unit, the direct equivalent (86 TOE/GWh) was used as practiced by all international databases, rather than the thermal equivalent (240 TOE/GWh) used by NEIS. One significant source that is missing here is the contribution from solar thermal systems.

Table 4: Primary energy sources in Sri Lanka in $2005^{12,13}$

\begin{tabular}{lrrrr}
\hline \multicolumn{1}{c}{ Fuel } & \multicolumn{2}{c}{ Annul energy supply } & & \\
& Original units + & kTOE & PJ & $\%$ \\
\hline Conventional & & & & \\
Petroleum & $4,139.44(\mathrm{kt})$ & $4,279.55$ & 179.18 & 46.16 \\
Biomass & $12,15457(\mathrm{kt})$ & $4,622.95$ & 193.56 & 49.87 \\
Coal & $92.74(\mathrm{kt})$ & 64.92 & 2.72 & 0.70 \\
Large Hydro & $3,124.00(\mathrm{GWh})$ & 268.66 & 11.25 & 2.91 \\
Alternatives & & & & \\
Small Hydro & $336.00(\mathrm{GWh})$ & 28.90 & 1.21 & 0.31 \\
PV Panels & $4.60(\mathrm{GWh})$ & 0.40 & 0.02 & 0.00 \\
Wind & $2.44(\mathrm{GWh})$ & 0.21 & 0.01 & 0.00 \\
Biomass & $12.15(\mathrm{kt})$ & 4.62 & 0.19 & 0.05 \\
\hline Total & & $9,270.21$ & 388.14 & 100.00 \\
\hline
\end{tabular}

The highest contribution comes from conventional biomass combustion for heat generation for cooking, baking, drying and firing earthen and ceramic ware. Its breakdown according to the 2003 Energy Balance Statement is given in Table 5. In estimating fuel wood consumption in household and commercial cooking, the use of low efficient conventional stoves has been assumed. However, in drying applications in the plantation and industrial sectors, the use of high efficient gasifier systems are now being introduced and hence, a certain fraction may need shifting to alternative category. Though fuelwood provides the major share of country's energy requirements, it is not collected in a systematic manner. It is traded in urban areas with supplies coming mostly from up-rooted rubber plantations, but in rural areas it is collected directly by the users from sources such as plantations, home gardens, crop land and natural forests $^{14}$.
Table 5: Consumption of fuel wood in different sub-sectors for $2003^{15}$

\begin{tabular}{lrr}
\hline Sector & Quantity (kt) & Th. Energy (PJ) \\
\hline Domestic & 8156 & 129.67 \\
Plantation Factories & 822 & 13.07 \\
Construction Items & 1860 & 29.57 \\
Bakery Products & 434 & 6.90 \\
\hline Total & 11,272 & 179.21 \\
\hline
\end{tabular}

If biomass were to replace petroleum sources to a significant factor as an alternative fuel, it is necessary to have a guaranteed supply through dedicated plantations to extract both the present and future requirements of biomass on a more sustainable manner. For this purpose, the Ministry of Science and Technology had carried out several trials in different parts of the country and has identified Gliricidia sepium as the most suitable short rotation coppice (SRC) crop for establishing such energy plantations. These trials also have revealed that the annual yield of woody biomass (grown at $1 \times 1 \mathrm{~m}$ spacing) is about $30 \mathrm{t} / \mathrm{ha}$ at $20 \%$ moisture content, which is equivalent to $24 \mathrm{t} / \mathrm{ha}$ of dry matter ${ }^{16}$.

The government as well as a few non-government organizations (NGO) have taken the initiative to develop AES in Sri Lanka since the 1970s, which included a biogas/solar/wind rural energy demonstration centre at Pattiyapola, solar home systems (SHS) in several model villages, village level micro-hydro systems, improved cooking stoves and biogas generators in villages ${ }^{17}$. Several NGOs such as Intermediate Technology Development Group (ITDG), Energy Forum, Integrated Development Association (IDEA) and Sarvodaya had facilitated the extension of these new systems into villages providing both technical and financial assistance.

In late-nineties, the Ministry of Power and Energy (MOPE) received funds from GEF through World Bank to implement a AE programme during 1997-2002 titled Energy Services Delivery (ESD) Project, which included a credit programme to support the introduction of AES - SHS, mini-hydro, a pilot grid-connected $3 \mathrm{MW}$ wind farm, and a capacity building component for the Ceylon Electricity Board $(\mathrm{CEB})^{18}$. A second GEF/WB funded project titled Renewable Energy for Rural Economic Development (RERED), was undertaken in 2002-2007, which comprised two components - a) grid-connected and off-grid power generation (hydro / wind / biomass) and b) off-grid solar PV systems ${ }^{19}$. The main objective of GEF projects was to facilitate the development of the solar and mini-hydro industries rather than provide assistance to the end-users.

Table 6 shows the composition of sources used for the generation of electricity in 2005 , according to which 
the conventional sources have contributed a little over $96 \%$. The $4 \%$ of AES is higher than that in many other developing countries and was made possible due to the support received from GEF through the World Bank to develop the private sector participation for exploiting AES, particularly the solar home systems (SHS), small- and mini-hydro plants and biomass sources at a commercial scale. The major contribution to AES share has come from the $\mathrm{SH}$ systems.

Table 6: Composition of sources used in the generation of electricity in $2005^{20}$

\begin{tabular}{lrrrr}
\hline Source & Quantity kt & $\begin{array}{c}\text { Th. Energy } \\
\text { PJ }\end{array}$ & \multicolumn{1}{c}{$\begin{array}{c}\text { Electricity } \\
\text { GWh }\end{array}$} & $\%$ \\
\hline Large Hydro & & & $3,124.00$ & 35.29 \\
Diesel Oil & 258.7662 & 10.826 & $1,266.67$ & 14.31 \\
Residual Oil & 262.9649 & 11.002 & $1,211.55$ & 13.69 \\
Fuel Oil & 473.6654 & 19.818 & $2,228.08$ & 25.17 \\
Naphtha & 123.8759 & 5.182 & 673.00 & 7.60 \\
\hline Conventional & & 46.830 & $8,503.30$ & 96.05 \\
\hline Small Hydro & & & 336.00 & 3.80 \\
Biomass & & & 6.44 & 0.07 \\
Solar PV & & & 4.60 & 0.05 \\
Wind & & & 349.44 & 0.03 \\
\hline Alternative & & & $8,852.74$ & 100.00 \\
\hline Total & & & & 3.95 \\
\hline
\end{tabular}

In the following sections, details of AES that could be established in Sri Lanka will be discussed under each of the technology sectors separately, along with a brief global situation analysis. There are many efficient technologies already developed and being developed in the world today for energy generation from AES. However, in this paper only those that have relevance to Sri Lanka will be discussed.

\section{Energy from plants}

Almost all plants have stems, branches and leaves commonly referred to in this paper as biomass. When woody biomass (such as Gliricidia) is burnt, carbon in it gets oxidized and releases thermal energy. Some crops produce cereals (such as soya bean, corn and maize) or tubers (cassava) containing carbohydrates or starch while a few others (such as sugar cane, sugar beet and sweet sorghum) produce sugar compounds. Energy from these substances could be obtained by fermenting them into alcohol, which can be used as a fuel. A few other crops (such as rape seed, palm oil, Jatropha) produce seeds containing oil, which after esterification could be used as a diesel-substitute. Biomass could also be gasified to produce syngas, while waste biomass could be subjected to anaerobic digestion to produce biogas which is a clean source of energy. Thus there are many ways of extracting energy from plants as detailed below.

\section{Land for energy plantations}

Plant energy sources considered in this paper are woody biomass in SRC species, bioethanol, biodiesel and biogas. The technologies for efficient extraction of energy from SRC species or conversion of crops to biofuels are well proven $^{21-23}$. The limiting factor for their adoption in Sri Lanka is the non-availability of adequate land. The present land use data are shown in Table 7, according to which $24 \%$ is under agriculture which comprises land under paddy, plantations and subsidiary crops; $37 \%$ comprise forests under the Forest Conservation Department (FCD) and the Wild Life Department (WLD). Somasekaram (1997) has estimated 1,025 kha as unusable land which covered waterways, reservoirs and tanks, steep land, land above $1525 \mathrm{~m}$ contour, barren land and marshes, and $900 \mathrm{kha}$ as land under homesteads and built-up areas. This leaves $611 \mathrm{kha}$ as the extent available for any new projects. In a study carried out by Perera et $a l .{ }^{24}$, land identified as sparsely used cropland and sparse forest/scrub land by aerial surveys are considered for energy plantations and other future uses. The results of the analysis based on different demand and production scenarios indicate that the total feasible land area available for energy plantations vary between 300 and $960 \mathrm{kha}$, with an average of $600 \mathrm{kha}$.

Table 7: Land use estimates in 2005/06 ${ }^{25,26}$

\begin{tabular}{lcc}
\hline Application & $\begin{array}{c}\text { Land extent } \\
(\mathrm{kha})\end{array}$ & $\begin{array}{c}\text { Percentage } \\
\%\end{array}$ \\
\hline Paddy & 709 & 10.82 \\
Plantations & 724 & 11.05 \\
Subsidiary crops & 150 & 2.29 \\
FCD Forests & 1,517 & 23.15 \\
WLD Forests & 916 & 13.98 \\
Land under vegetation & 4,016 & 61.29 \\
Unusable & 1,025 & 15.64 \\
Homesteads \& built up & 900 & 13.74 \\
Sparsely used \& balance & 611 & 9.33 \\
\hline Total & 6,552 & 100.00 \\
\hline
\end{tabular}

A study conducted by the Ministry of Science and Technology has revealed that nearly 1.6 Mha of land remain degraded and under utilized in Sri Lanka ${ }^{27}$, and these could be converted into sustainable SRC plantations with Gliricidia. A preliminary investigation covering an area of 52 kha has revealed that only $80 \%$ of this land is suitable ${ }^{4}$ for agriculture. In extending this ratio to the entire island, one may assume another $80 \%$ as the availability factor which would give the extent suitable and available for sustainable energy 
plantations as 1.0 Mha. Since this land has to be used for all three biofuels, it is assumed that it will be equitably distributed among the crops producing wood, bioethanol and biodiesel, identifying the best sites for the specific species.

In Sri Lanka, a large extent of land, about 700 kha is under paddy. There has been a general decline in the cultivated area as paddy land has been allowed to go into fallow. According to Census and Statistics Department data, an average of $41 \%$ or approximately 55 kha of paddy land have been abandoned in the wet zone alone, the highest decline of $82 \%$ being in Colombo District (Table 8). Though there appears to be some effort to bring this land under paddy cultivation again in view of the government's decision to acquire any uncultivated land, some of this land, say about $50 \%$ or 28 kha could be utilized for growing energy plantations, especially Jatropha.

Table 8: Paddy land abandoned in the low-wet zone between $1974 / 75$ and $2004 / 05^{28,29}$

\begin{tabular}{|c|c|c|c|c|}
\hline \multirow[t]{2}{*}{ District } & \multicolumn{2}{|c|}{ Paddy land in fallow (ha) } & \multicolumn{2}{|c|}{ Decline } \\
\hline & $\begin{array}{c}\text { Maha } \\
\text { 1974/75 }\end{array}$ & $\begin{array}{c}\text { Maha } \\
\text { 2004/05 }\end{array}$ & (ha) & $\%$ \\
\hline Colombo & 25,750 & 4,593 & 21,157 & 82.2 \\
\hline Gampaha & 18,000 & 10,173 & 7,827 & 43.5 \\
\hline Kalutara & 21,177 & 13,642 & 7,535 & 35.6 \\
\hline Galle & 23,574 & 14,498 & 9,076 & 38.5 \\
\hline Matara & 20,027 & 14,863 & 5,164 & 25.8 \\
\hline Ratnapura & 14,913 & 12,418 & 2,495 & 16.7 \\
\hline Kegalle & 11,237 & 8,922 & 2,315 & 20.6 \\
\hline Total & 134,678 & 79,109 & 55,569 & 41.3 \\
\hline
\end{tabular}

Recently, the Mahaweli Authority has called for proposals from potential investors to release 5000 ha out of 14,000 ha of land available with them in System B for commercial cultivation possibly of agriculture crops. It is assumed that 10,000 ha could be made available for energy plantations possibly with sweet sorghum. It is the practice to cultivate Gliricidia in tea plantations for shade, particularly in low-grown areas. At present, there is no effort being made to harvest this wood systematically even for firewood. If harvesting is done during rainy season when the cloud cover provides necessary shading, stems could be used for combustion and leaves as green manure. With about 110 kha under tea in the low country, a fraction of this land, say about $50 \%$ or $55 \mathrm{kha}$, could be made available for Gliricidia plantations in a systematic manner to extract energy.

Gliricidia is also planted in coconut estates, particularly in the coconut triangle, as an under crop. Out of the total extent of about 390 kha of land under coconut, at least $25 \%$ or 100 kha could be assumed to be brought under Gliricidia. It is suggested that any new land allocated for ethanol production will be cultivated mostly with sweet sorghum (300 kha) which has low water requirements and resilient to droughts, and the balance only (50 kha) with sugar cane. The total land available for energy plantations could now be summarized as given in Table 9.

Table 9. Land likely to be available for energy plantations

\begin{tabular}{llcc}
\hline Type of land & $\begin{array}{l}\text { Proposed } \\
\text { cultivation }\end{array}$ & $\begin{array}{c}\text { Estimated } \\
\text { extent (kha) }\end{array}$ & $\begin{array}{c}\text { Available } \\
\text { extent (kha) }\end{array}$ \\
\hline $\begin{array}{l}\text { Sparsely used land } \\
\text { allocated equitably }\end{array}$ & $\begin{array}{l}\text { Total } \\
\text { Gliricidia }\end{array}$ & $600-1,600$ & 350 \\
& Sweet Sorghum & 350 \\
& Sugarcane & 50 \\
& Jatropha & 55 & 350 \\
Paddy land in fallow & Jatropha & 14 & 10 \\
Mahaweli System B & Sweet Sorghum & 27 & 27 \\
Sugar factories & Sugarcane & 110 & 55 \\
Low country tea & Gliricidia & 390 & 100 \\
Coconut Triangle & Gliricidia & & 1,270 \\
\hline Total & & & \\
\hline
\end{tabular}

\section{Specific energy potential from plantations}

For completely dry wood (oven-dry), the amount of energy per unit of weight is more or less the same for all wood species, with an average for Gross Heating Value (GHV) of $20 \mathrm{MJ} / \mathrm{kg}$ for stem wood $^{31}$. However, the Net Heating Value (NHV) for wood is about $10 \%$ less. Also, the moisture content lowers the heating value at the rate of $2 \mathrm{MJ} / \mathrm{kg}$ for every $10 \%$ increase of moisture. This gives a NHV of $16 \mathrm{MJ} / \mathrm{kg}$ for air dried wood with moisture content $10 \%$. This is about $2 / 3 \mathrm{rd}$ that of coal which has a NHV ranging from 22 to $26 \mathrm{GJ} /$ tonne depending on the source.

The limited land available in the island has to be apportioned among the crops required for producing thermal energy (i.e.Gliricidia), bioethanol (i.e. sugar cane/sweet sorghum/cassava) and biodiesel (i.e. Jatropha), taking into consideration the suitability of land for specific crops. In order to optimize the utilization of land one must also consider the potential energy generation capacity of each of these crops, which would vary from $45 \mathrm{GJ} /$ ha for Jatropha to $990 \mathrm{GJ} /$ ha for sweet sorghum, $373 \mathrm{GJ} /$ ha for sugar cane with energy extracted from bagasse and molasses, and $384 \mathrm{GJ} / \mathrm{ha}$ for Gliricidia (see Table 10). 
Table 10: Energy generation potential per hectare of different crops ${ }^{32-34}$

\begin{tabular}{lccc}
\hline \multicolumn{1}{c}{ Crop } & $\begin{array}{c}\text { Biofuel yield } \\
\text { t/ha/year }\end{array}$ & $\begin{array}{c}\text { Cal. value } \\
\text { GJ/t }\end{array}$ & $\begin{array}{c}\text { Energy yield } \\
\text { GJ/ha/year }\end{array}$ \\
\hline Gliricidia & 24 & 16 & 384 \\
Sugarcane - total & 60 & & 373 \\
$\quad$ Bagasse (1/3 of cane) & 20 & 18 & 360 \\
$\quad$ Ethanol from molasses & 0.5 & 27 & 13 \\
$\quad$ Ethanol from sugar) & 4.0 & 27 & $(108)$ \\
Sweet sorghum - total & 120 & & \\
$\quad$ Ethanol from grain & 0.9 & 27 & \\
$\quad$ Ethanol from stalk & 7.6 & 27 & 205 \\
$\quad$ Ethanol from residue & 1.6 & 27 & 43 \\
$\quad$ Bagasse & 40 & 18 & 720 \\
Jatropha & 1.2 & 38 & 45 \\
\hline
\end{tabular}

Production of bioethanol from cane juice was not considered as it would affect the sugar production, though it is shown for the sake of completeness. It was assumed that $1 / 3$ of cane crushed ends up as bagasse. Sweet sorghum gives the highest potential. The data shown here are only indicative as actual values depend on many external and site-specific factors.

\section{Direct combustion of biomass}

In developed countries, highly-efficient combustion technology is used under tight regulations on emissions to extract energy from biomass. In developing countries on the other hand, traditional technologies comprising mostly three-stone open stoves that are both inefficient and highly polluting are used. In the former case statistics on biomass use are available, as commercially traded fuel wood is used, while in the latter fuel wood is collected directly from village sources and as such actual data are not available and only estimates are used. The global fuel wood consumption per capita is shown in Table 11, according to which the highest consumption is in Africa where a large number of countries fall under the category of least developed countries, followed by South American countries, and the least is in North America. In Asia the per capita counsumption of biomass in the South Asian countries is more than that consumed by the rest of the regions, which include the Middle East.

Table 11: Global Fuel-wood Consumption - $2005^{35}$

\begin{tabular}{lr}
\hline Region & kg per capita \\
\hline Africa & 305 \\
North America & 70 \\
LA \& Caribbean & 246 \\
South Asia & 129 \\
Asia - rest & 81 \\
Europe & 102 \\
Oceania & 172 \\
\hline
\end{tabular}

The total installed capacity of efficient biomass combustion systems world over in 2006 for heating (235 GW) was more than five times than that for electricity generation $(45 \mathrm{GW}$ ) (see Table 3 ). The estimated total biomass-generated electricity in 2005 world-wide was about 183 TWh (see Table 12). Biomass continues to be the major source of energy in most developing countries. Its contribution is in excess of $90 \%$ in some least developed countries in Africa and about 55\% in South Asia while it is $3-4 \%$ in Europe and North America ${ }^{36}$. In recent times there have been efforts to disseminate improved cook stoves (ICS) world-over. China has installed about 180 million ICSs representing about 95 percent of biomass consuming households and India about 34 million ICSs, representing about 25 percent of such households ${ }^{37}$.

Table 12: Major countries producing electricity from biomass $-2005^{38}$

\begin{tabular}{lcc}
\hline Country & Energy TWh & Percentage \\
\hline USA & 56.3 & 30.7 \\
Germany & 13.4 & 7.3 \\
Brazil & 13.4 & 7.3 \\
Japan & 9.4 & 5.1 \\
Finland & 8.9 & 4.9 \\
UK & 8.5 & 4.6 \\
Canada & 8.5 & 4.6 \\
Spain & 7.8 & 4.3 \\
Others & 57.1 & 31.2 \\
\hline World & 183.3 & 100 \\
\hline
\end{tabular}

In Sri Lanka, around $50 \%$ of the primary energy comes from biomass in recent times ${ }^{39}$. It is assumed that only traditional methods of combustion are used with very low efficiencies of about $8-13 \%$. With increased importance given to utilization of renewable energy sources, techniques have been developed and commercialized to improve the combustion efficiencies and reduce polluting emissions ${ }^{40}$. As shown in Table 5, the largest usage of biomass in Sri Lanka is in domestic and commercial cooking, using the traditional stoves. Several organizations have developed improved cook stoves (ICS) with higher efficiencies - about $18-24 \%{ }^{41}$. Field monitoring in Sri Lanka has found that the use of ICS results in about $33 \%$ saving of biomass relative to traditional stoves ${ }^{42}$. With about 25,000 potters trained in the manufacture of ICSs, it is estimated that the annual production is around 300,000, and that around 01 million ICSs are currently in use in Sri Lanka ${ }^{43}$, which is approximately $25 \%$ of the households in the country.

In 1992, an Inter-ministerial Committee appointed by the Ministry of Power and Energy had recommended the promotion of wood-fueled dendro power plants and this proposal had received the Government approval in 
$1993^{44}$. As a possible follow up to this recommendation, the Ministry of Science and Technology had established a separate unit on Alternative Energy within the Ministry and has undertaken a programme to promote the plantation of SRC crops and build pilot scale dendropower plants. With the successful demonstration of the feasibility of dendro-power, the Government has again appointed an Inter-Ministerial Working Committee on Dendro Thermal Technology in 2004 to prepare an action plan to develop biomass powered electricity generation industry to a much larger scale ${ }^{45}$.

Studies undertaken by Perera et al..$^{46}$ have shown that the total annual energy potential of bio-energy plantation could be in the range 30-150 PJ in Sri Lanka under different demand and production scenarios. The corresponding range of total annual electricity generation potential, with a production rate of $1 \mathrm{MWh}$ of electricity per $1 \mathrm{t}$ of fuelwood, would be $2-10 \mathrm{TWh}$. These figures indicate that the biomass based electricity generation could contribute significantly to avoid the use of imported oil and coal to meet the increasing energy demand in the future. Perera et al. ${ }^{47}$ have also estimated the energy potential in biomass residue from agriculture fields and industries considering available data on residue to product ratios and collection factors and concluded that the total potential, which is of the order of $63 \mathrm{PJ}$, is a significant source for generation of electricity.

If the presently under-utilized land and other land are cultivated with Gliricidia, Sorghum and sugar cane as suggested in Table 9, the total thermal energy that could be derived out of these crops will be almost $292 \mathrm{PJ}$ as shown in Table 13. It is assumed that the yield of biomass from Gliricidia in mixed plantations is half that of dedicated plantations because of the low plantation density. In comparison, the present total energy consumption in Sri Lanka as given in Table 4 is 9,270 kTOE or 388 PJ, out of which the thermal energy component of electricity generation is only $46.8 \mathrm{PJ}$ (Table 6). The total biomass consumption in 2005 was $179 \mathrm{PJ}$ (Table 5), out of which the domestic sector consumed 130 PJ with the rest consumed by industries, and these were met from existing sources. Therefore the present thermal energy requirement for electricity generation (47 PJ) could be easily with the proposed new plantations even if only $1 / 6$ the proposed extent is planted. The additional plantation output could be sold as chips required for firing efficient biomass stoves enabling more penetration of these stoves in urban areas.
Table 13. Potential thermal energy available from energy plantations

\begin{tabular}{lrrrrr}
\hline \multicolumn{1}{c}{ Crop } & $\begin{array}{c}\text { Extent } \\
\text { kha }\end{array}$ & $\begin{array}{c}\text { Yield } \\
\text { t/ha }\end{array}$ & $\begin{array}{c}\text { Crop/ } \\
\text { Bagasse } \\
\text { yield kt/year }\end{array}$ & $\begin{array}{c}\text { Calorific } \\
\text { value GJ/t }\end{array}$ & $\begin{array}{r}\text { Potential } \\
\text { energy PJ }\end{array}$ \\
\hline Gliricidia $^{l}$ & 350 & 24 & 8,400 & 16 & 134 \\
Gliricidia $^{2}$ & 155 & 12 & 1,860 & 16 & 30 \\
Sorghum Bagasse $^{2}$ & 310 & 18 & 5,580 & 18 & 100 \\
Sugar cane Bagasse & 77 & 20 & 1,540 & 18 & 28 \\
\hline Total & & & & & 292 \\
\hline 1= dedicated; $2=$ mixed & & & &
\end{tabular}

With the encouragement given by the Government in terms of tax concessions and power purchase agreements, several investors have come forward with proposals to set up biomass based power plants. The first commercial dendro power plant in Sri Lanka with capacity $1 \mathrm{MW}$ was built at Walapane and it adds annually $6447 \mathrm{MWh}$ of electricity to the national grid consuming $40 \mathrm{t}$ of fuel wood a day ${ }^{48}$. Another grid-connected $1 \mathrm{MW}$ plant fired with coconut residue is in operation at Badalgama $^{49}$. Letters of intent (LOI) have been issued to build several more biomass fired small power plants; an agro-waste $9.8 \mathrm{MW}$ plant ${ }^{50}$, a paddy husk fired $3 \mathrm{MW}$ plant in Polonnaruwa, a paddy husk/Gliricidia fired 6 MW plant in Dehiattakandiya. and a Gliricidia fired 5 MW Co-Generation plant at Thulhiriya ${ }^{51}$. Studies are being carried out by a cement manufacturer to build a paddy husk and wood chip fired 6.6 MW power plant at their cement grinding facility in Trincomalee. The Energy Forum is working on the establishment of a Dendro Power Pilot Project to provide off-grid power to a village community of 100 households from a Gliricidia plantation at Badalkumbura ${ }^{52}$. It is expected that at least 10 households will earn their livelihood from the project.

\section{Biofuels from plants}

The term biofuel is generally used to describe liquid fuels manufactured from biomass for the transport sector. The two most common biofuels are bioethanol - made from sugar and starch - and biodiesel - made from vegetable oils. Bioethanol is used in spark-ignited engines in place of gasoline, while biodiesel is used in compressionignited engines in place of diesel oil. 


\section{Bioethanol production}

The total world production of bioethanol in 2006 has been $38.653 \mathrm{Mt}$ (Table 14). USA is the largest producer with $37 \%$ share and the second is Brazil with $35 \%$ share followed by China ( $8 \%$ ), India (4\%) and several European countries. In Brazil, the feedstock is totally from sugar cane, while in USA and China, it is from corn and molasses. India depends on molasses and other crops like sweet Sorghum.

Table 14. Global production of bioethanol in $2006^{53}$

\begin{tabular}{lcc}
\hline Country & Quantity (Mt) & Percentage (\%) \\
\hline U.S. & 14.580 & 37.72 \\
Brazil & 13.487 & 34.89 \\
China & 3.054 & 7.90 \\
India & 1.508 & 3.90 \\
France & 0.754 & 1.95 \\
Germany & 0.607 & 1.57 \\
Russia & 0.514 & 1.33 \\
Canada & 0.459 & 1.19 \\
Spain & 0.366 & 0.95 \\
South Africa & 0.306 & 0.79 \\
Thailand & 0.279 & 0.72 \\
Other & 2.738 & 9.818 \\
World & 38.653 & 100.00 \\
\hline
\end{tabular}

Diversion of food crops that yields sugar and starch meant for human consumption to bioethanol manufacture has resulted in escalation of prices of food raising issues on priorities - food or fuel. This problem could be averted if cellulosic material such as grass, agriculture residue, tree toppings, wood industry waste and municipal solid waste could be used for the manufacture of bioethanol. Cellulosic substances are available in abundance and their accumulation without a proper disposal mechanism has today become an environmental issue. If these material could be used for producing bioethanol, it will be a solution to a burning environmental problem too. However, conversion of cellulose to bioethanol is somewhat of a difficult process because of the complex nature of its constitution. These difficulties have been overcome by resorting to biotechnology, but the technology is still in the nascent stage. The commercial scale manufacture of bioethanol from cellulosic material today is limited to a few companies. Once this technology is freely available, bioethanol is expected to replace petroleum fuel in transport to a significant extent.
Bioethanol has certain limitations as a direct substitute for gasoline and for distribution using the existing infrastructure. Its heating value is only 26 $\mathrm{MJ} / \mathrm{kg}$ compared to $41 \mathrm{MJ} / \mathrm{kg}$ for gasoline. Bioethanol causes corrosion in containers and pipelines, and hence it is necessary to either add corrosion inhibitors or use material not susceptible to corrosion. On the other hand, bioethanol has high anti-knock properties, making it suitable as an anti-knock agent, and is already being blended for that purpose. It has high oxygen content which improves the engine efficiency and combustion.

In the production process, bioethanol is initially produced in hydrous form containing about 5\% moisture. However, for blending with gasoline, moisture has to be removed to below $1 \%{ }^{54}$. Otherwise the blend will not be stable. Removal of water is somewhat an expensive and energy consuming process, which makes anhydrous bioethanol costlier. Hydrous bioethanol is not recommended for use in vehicles with regular engines as it damages engine components. In Brazil only vehicles with modified engines are fueled with hydrous bioethanol. Even gasoline blended with anhydrous bioethanol can be used in regular engines only up to about $20 \%$ blend, and increasing the ratio beyond this point requires engine modification. Modified or flexi-vehicles are available in western countries which can run on blends up to $85 \%$ of bioethanol. Most countries have taken policy decisions to blend all gasoline marketed with $5-10 \%$ of bioethanol in the short term.

In Sri Lanka, the possible feedstocks that could be used for the manufacture of bioethanol are sugar molasses or sweet sorghum and starchy material such as cassava and maize. In view of the demand for sugar, it is not possible to divert the cane yield even partially to produce bioethanol. Currently only the factories at Pelawatte and Sevanagala produce sugar. During $2004 / 05$, a total of 14,650 ha were under sugar cane ${ }^{55}$. The other two factories at Kantale and Hingurana were closed down more than a decade ago. Previously these two factories had produced nearly $12 \mathrm{kt}$ of sugar annually between the two in 1992, with 4,600 ha of land under them ${ }^{56}$. These two factories alone were expected to bring 12,400 ha under cultivation by 1968 , but had cultivated only 6,000 ha even by $1980^{57}$. If the production at both these factories are revived, and assuming that the entire land allocated in the sixties is still available, a total of over 27 kha of land would be available with a potential sugar production of $126 \mathrm{kt}$ annually. 
In 2004/05, Pelawatte and Sevanagala factories have jointly produced 7.06 million litres of alcohol from 737 $\mathrm{kt}$ of cane harvested from 13,600 ha of sugar cane ${ }^{58}$. Taking the same ratio of alcohol to cane harvested (9.6 L per tonne of cane or $520 \mathrm{l} / \mathrm{ha}$ ), the potential production of alcohol would be about $14 \mathrm{Ml}$ in the short term. Assuming that the present demand for consumption and other uses is kept the same, only the balance $7 \mathrm{Ml}$ or $6 \mathrm{kt}$ will be available for blending with gasoline. With approximately $600 \mathrm{kt}$ of current consumption of gasoline, the rehabilitation of the sugar industry could alone meet only about $1.0 \%$ of the gasoline demand.

A promising new crop being tried out in India for the manufacture of bioethanol is sweet sorghum. Its stalk has sugar which can be extracted and its cereal gives starch for use as an animal feed or fermented into sugar and bioethanol. Being a C4 plant, it needs little water and can be grown in marginal land. A new hybrid variety developed in USA yields about $3 \mathrm{t}$ of grain and about 12,000 litres of ethanol per hectare in one year ${ }^{59}$, extracting it from grain, juice and molasses, while the Indian variety yields only about $6,300 \mathrm{~L} / \mathrm{ha} / \mathrm{y}$ with two crops a year ${ }^{60}$. With the land allocation for cultivation of sweet sorghum as shown in Table 9, the total bioethanol production could be increased by several fold - up to about $3 \mathrm{Mt}$ annually using USA variety - as shown in Table 15. Its heat content, however, is the same as that of $2 \mathrm{Mt}$ of gasoline which is more than 3 times consumed in 2006. Thus, with $1 / 3$ the spare land brought under sweet sorghum cultivation and rehabilitation of all the sugar cane plantations, it is possible to totally replace the present and future consumption of gasoline.

Table 15: Potential production of bioethanol in Sri Lanka

\begin{tabular}{lccccc}
\hline \multicolumn{1}{c}{ Crop } & $\begin{array}{c}\text { Extent } \\
\text { kha }\end{array}$ & $\begin{array}{c}\text { Bioethanol } \\
\text { yield t/ha/y }\end{array}$ & $\begin{array}{c}\text { Potential } \\
\text { quantity } \\
\text { kt/y }\end{array}$ & $\begin{array}{c}\text { Calorific } \\
\text { value } \\
\text { GJ/t }\end{array}$ & $\begin{array}{c}\text { Potential } \\
\text { energy } \\
\text { PJ }\end{array}$ \\
\hline $\begin{array}{l}\text { Sweet Sorghum } \\
\begin{array}{l}\text { Sugar cane } \\
\text { (Molasses) }\end{array}\end{array}$ & 310 & 10.1 & 3,131 & 27 & 84 \\
\hline Total 2,983 & & 0.5 & 38 & 27 & 01 \\
\hline
\end{tabular}

Another alternative to gasoline is biobutanol, the hydroxide of the fourth alkane - butane. This has properties including the calorific value very similar to those of gasoline and can be used as its direct substitute with similar performance without any modification to the engine. It can be produced from biomass as for ethanol, but the required enzymes are still a proprietary material $^{61}$.

\section{Biodiesel production}

The term biodiesel is used to describe the methyl ester of fatty acid obtained after reacting a vegetable oil or animal fat with methanol in the presence of a catalyst - usually sodium or potassium hydroxide. The reaction also produces glycerin as a byproduct. Generally, 10 parts of oil and 1 part of methanol produce 10 parts of ester and 1 part of glycerin ${ }^{62}$. A variety of vegetable oils can be used to make biodiesel, ranging from oils of soya bean (USA), rape seed (Germany) and sunflower seed (EU) in temperate countries to Jatropha (India) and palm (Malaysia) oils in tropical countries.

The productions of biodiesel in different countries in 2006 are shown in Table 16, with a total of $6.42 \mathrm{Mt}$, which is about $1 / 6$ th that of bioethanol produced in the same year. The highest amount is in Germany where the main feedstock is rape seed oil. Worldwide, 92\% of biodiesel is manufactured from rapeseed, $10 \%$ from sunflower seed, $5 \%$ from soya bean and 3\% from palm oil $^{63}$. Biodiesel could also be produced from rubber seed oil, but the yield $(0.15 \mathrm{t} / \mathrm{ha} / \mathrm{y}$ of seed and $0.04 \mathrm{t} / \mathrm{ha} / \mathrm{y}$ of oil $)^{64}$ is too low to make it a significant source.

Table 16: Global production of biodiesel in $2006^{65}$

\begin{tabular}{lcc}
\hline Country & Quantity $(\mathrm{kt})$ & Percentage $(\%)$ \\
\hline Germany & 2,662 & 41.44 \\
USA & 833 & 12.97 \\
France & 743 & 11.57 \\
Malaysia & 600 & 9.34 \\
Italy & 447 & 6.96 \\
UK & 192 & 2.99 \\
Austria & 123 & 1.91 \\
Poland & 116 & 1.81 \\
Czech Rep. & 107 & 1.67 \\
China & 100 & 1.56 \\
Other & 500 & 7.79 \\
\hline World & 6,423 & 100.00
\end{tabular}

In view of adopting national policies promoting biodiesel usage, there is a high demand for biodiesel in Europe, and this is met from imports. The main exporters are USA, Malaysia and China. India and several other countries have commenced trials with Jatropha plantations to produce biodiesel for their own use. Jatropha curcas is a shrub growing in tropical countries even under adverse climatic and marginal soil conditions, 
which yields about $30-40 \%$ of oil from its seeds. Trials done in India have shown that 1 ha of Jatropha produces about $3.75 \mathrm{t}$ of seeds and $1.2 \mathrm{t}$ of oil annually, which can yield an equal quantity of biodiesel. Initially, India has released 400,000 ha of land for this purpose, but no commercial scale productions have commenced yet.

Generally, pure biodiesel is not used in regular vehicles as it attacks engine parts containing elastomer compounds. Blends up to about $20 \%$ biodiesel with normal diesel show no damage, and the use of higher ratios needs engine modification ${ }^{66}$. Like in the case of bioethanol, most countries have taken policy decisions to incorporate biodiesel in regular diesel in the short term, the EU target being $5.75 \%$ and $10 \%$ for 2010 and 2020, respectively ${ }^{67}$.

With the land allocations shown in Table 9 for energy plantations, Sri Lanka has the potential to produce annually $458 \mathrm{kt}$ of biodiesel or $405 \mathrm{kt}$ after adjusting for low heating value, as shown in Table 17, and this is about $21 \%$ of the country's annual consumption of $1880 \mathrm{kt}$ of diesel. Therefore, blending of diesel oil with $10-20 \%$ of biodiesel will be feasible, provided the required land could be obtained and it could be produced at a cost on par with imported fuel.

Table 17: Potential production of biodiesel in Sri Lanka

\begin{tabular}{lccccc}
\hline \multicolumn{1}{c}{ Source } & $\begin{array}{c}\text { Extent } \\
\text { kha }\end{array}$ & $\begin{array}{c}\text { Biodiesel } \\
\text { yield } \\
\text { t/ha/y }\end{array}$ & $\begin{array}{c}\text { Potential } \\
\text { quantity } \\
\mathrm{kt} / \mathrm{y}\end{array}$ & $\begin{array}{c}\text { Calorific } \\
\mathrm{GJ} / \mathrm{t}\end{array}$ & $\begin{array}{c}\text { Potential } \\
\text { energy } \\
\mathrm{PJ}\end{array}$ \\
\hline $\begin{array}{l}\text { Jatropha in new land } \\
\text { Jatropha } \text { in paddy }\end{array}$ & 350 & 1.2 & 420 & 38 & 15.6 \\
land in fallow & 28 & 1.2 & 33 & 38 & 1.2 \\
Rubber seed & 118 & 0.04 & 5 & 38 & 0.2 \\
\hline Total & & & & 458 & 17 \\
\hline
\end{tabular}

\section{Conversion of biomass into gaseous fuel}

Biomass could be first converted into gaseous fuels, which burn efficiently with minimum pollution. There are two ways of doing this; one is gasification of woody biomass and the other is the anaerobic digestion of waste biomass including municipal solid waste.

\section{Biomass gasification}

Burning of wood under reduced conditions produces a mixture of gases, mainly hydrogen and carbon monoxide, called syngas. This gas when used to fire thermal systems such as boilers, kilns and ovens results in high efficiencies (about $80 \%$ ) of heat extraction ${ }^{68}$ and about $50 \%$ in electricity generation ${ }^{69}$. The (NERD) Centre has been developing gasifier systems of capacities in the range $150-250 \mathrm{kWth}$ for use in crematoria and industry ${ }^{70}$. However, their demand has been declining because of two reasons; one is the regular attention that this apparatus needs for proper operation and the other is the difficulty in getting a regular supply of fuel wood. A private company has installed several gasifiers of 1,000 $\mathrm{kWth}$ range in various industries, which are working satisfactorily. NERD has also developed a gasifier type cook stove for domestic use. This has the potential as a substitute for a gas cooker provided the necessary wood chips are made available at retail shops in urban areas.

Syngas could be directly used to operate an internal combustion engine and it was in fact practiced during war time when petroleum oil was in short supply. Because the gas was produced in situ and the apparatus was bulky, it did not become popular when petroleum was freely available. However, it has been possible to synthesize light hydrocarbons from $\mathrm{CO}$ and $\mathrm{H}_{2}$ present in syngas by passing these two gases over catalytic material at elevated temperature and pressure. Depending on the catalyst and ambient conditions, different types of hydrocarbons could be produced, which includes Methanol and Dimethyl Ether (DME). Methanol is a biofuel that could be used in place of gasoline in sparkignited vehicles, though it has a heating value lesser than that of gasoline. DME, which is a gas at ambient temperature and pressure, could be easily liquefied like LPG, and transported. It has a cetane value similar to that of petroleum diesel, and hence could be used as a substitute for diesel. It is safe to handle, non-toxic and could be used as a substitute for LPG as a domestic and commercial fuel ${ }^{71}$. Its heating value, however, is lower by about $30 \%$ than that of petroleum diesel.

Studies have shown that 1 tonne of wood after gasification and synthesis could produce about $700 \mathrm{~L}$ of methanol $^{72}$. The present annual gasoline consumption being about $600 \mathrm{Ml}$, this amount could be produced from wood harvested from about $60 \mathrm{kha}$, which is only $1 / 5$ the land allocated for ethanol production using sugar/starch fermentation. Integrated studies on wood gasification and DME synthesis carried out by Wang et al. have shown that $1 \mathrm{~kg}$ of dry wood produces on an average $240 \mathrm{~g}$ of DME under laboratory conditions ${ }^{73}$. If this process is commercialized and DME made available freely it will be a better fuel than biodiesel, particularly because of its high yield. If the $375 \mathrm{kha}$ allocated to Jatropha is planted with Gliricidia and the harvested 
wood is gasified and converted into DME, the annual yield will be 2,250 kt, and this has the heat equivalent of 1,550 $\mathrm{kt}$ of petroleum diesel. Thus, cultivation of Gliricidia instead of Jatropha will enable $82 \%$ substitution of diesel, instead of $21 \%$ anticipated with Jatropha oil. DME is a compound that has been targeted for future use as a fuel in several countries around the world, led by China and Japan ${ }^{74,75}$.

\section{Biogas generation}

The concept of generating biogas was introduced in the 1970s and several thousands of biogas digesters were installed in the country. The first community scale digester was built in late seventies at Pattiyapola as part of the UNDP Renewable Energy Programme. The gas was used to drive a diesel generator to provide electricity to the village but the programme was abandoned when the grid was extended to the village. Biogas comprises a mixture of methane (60-70\%) and carbon dioxide (30$40 \%)$ and is produced during the anaerobic digestion of organic matter including human, animal, and plant waste.

In a typical biogas generator, organic matter along with cow dung is fed into pits built below ground. The pit is covered with an up-turned cylinder in which gas is collected. The gas can be burned to generate heat for cooking and for providing light using a mantle lamp. The sludge is removed regularly for use as a fertilizer. The capacity may vary from small domestic units to large units built to accommodate municipal market waste. In Sri Lanka, it is estimated that there are about 3000 small biogas units installed in villages across the island ${ }^{76}$. Two demonstration scale municipal digesters built by the NERD Centre are in operation at Kirulapone and Muthurajawela. Many of the plants built years ago have been abandoned for want of proper maintenance, which is an important factor for their sustenance.

Sri Lanka's present cattle and buffalo populations stand at 1.214 million and 0.314 million, respectively ${ }^{77}$. According to the Bio-Energy Association, a herd of 6 cattle produces $32 \mathrm{t}$ of dung a year sufficient to produce $1,900 \mathrm{~m}^{3}$ of biogas annually ${ }^{78}$. If dung from half of this population could be fed into digesters spread across the island, and assuming a calorific value of $27 \mathrm{MJ} / \mathrm{m}^{3}$ for biogas, the total energy that could be produced will be about 6.5 PJ/year. When carried out on a commercial scale, biogas could be compressed and transported to user sites for thermal, lighting and transport applications, as a substitute for LPG. With the government's policy to expand the livestock industry, there will be a potential to produce $10 \mathrm{PJ}$ of biogas energy annually.

\section{Energy from Municipal solid waste}

Municipal Solid Waste (MSW) is generally disposed in sanitary landfills with facilities for collection of methane that is emitted after bio-degradation. However, several attempts by the government to establish such landfills met with resistance from the public and presently MSW is disposed in several open dump sites. The disposal of this waste continues to be both a social and environmental problem for the last several decades. The Western Province generates about 1,900 t of MSW a day, out of which Colombo city alone generates about $800 \mathrm{t}^{79}$. Among different local bodies in the province, the fraction of biodegradable matter in MSW varies from $50 \%$ to $94 \%$, with $83 \%$ for Colombo city ${ }^{80}$. As a solution to this problem, a company has offered to build a $40 \mathrm{MW}$ power plant consuming $1000 \mathrm{t}$ of mixed MSW a day ${ }^{81}$. The plant will gasify the waste at very high temperature before feeding into the combustion chamber. In the meantime, letters of intent have been issued to 10 other parties to build MSW fired power plants with aggregate capacity of $50 \mathrm{MW}^{82}$.

Perera et $\mathrm{al}^{83}$ have assumed that all MSW collected in the country ( $2.8 \mathrm{kt} /$ day in 2005$)$ could be disposed in sanitary landfills resulting in the recovery of $90 \mathrm{kt}$ of methane a year which has the potential to generate 4.5 PJ of energy. In view of the high organic mater in the waste collected within the city, it would be prudent to sort and convert its biodegradable matter into biogas as has been demonstrated and then use that gas to fire a generator or other thermal appliance. The rest could be recycled into useful products and the compost could be used in cultivation. A long term power generation project using MSW will be a disincentive for commencing a programme to reduce, reuse and recycling of waste.

\section{Small hydro power systems}

Hydropower plants rated below $10 \mathrm{MW}$ are referred to

Table 18: Installed and planned small hydro plants globally ${ }^{84}$

\begin{tabular}{lcc}
\hline \multicolumn{1}{c}{ Region } & $\begin{array}{c}\text { Installed capacity in } \\
\text { 2005 - MW }\end{array}$ & $\begin{array}{c}\text { Future planned } \\
\text { capacity- MW }\end{array}$ \\
\hline North America & 3,925 & 16 \\
South America & 1,751 & 2,044 \\
Asia 3,991 & 1,333 & \\
Europe & 10,223 & 985 \\
Middle East & 107 & 136 \\
Africa & 117 & 4 \\
Oceania & 108 & 7 \\
\hline World & 20,222 & 4,525 \\
\hline
\end{tabular}


as small hydro $(\mathrm{SH})$ plants in this study. Such plants fall into a range of categories; small (1-10 MW), mini(0.1-1 MW), micro-(10-100 kW) and pico-plants (1-10 $\mathrm{kW})$. Generally, small and mini-hydro plants are gridconnected, while micro- and pico- level plants are not connected to the grid. The main attraction of these plants is that they could be built with relatively small capital. However, they do make adverse impacts on the environment by depriving water for other uses as well as to fauna and flora in between the points of extraction and discharge. Another shortcoming of small hydro systems is the non-reliability of available energy, particularly during lean flow periods, resulting in a low plant factor.

According to WEC 2007 report, SH plants are popular even in developed countries. Table 18 shows the installed capacity of SH plants that were in operation in different regions at the end of 2005. USA and Brazil, two countries having large numbers of SH plants amounting to 2,388 MW and 1,429 MW, respectively, of installed capacity, have been generating electricity at plant factors of $51 \%$ and $53 \%$, respectively.

During the $18^{\text {th }}$ and $19^{\text {th }}$ centuries, about 500 mini-hydro systems had been installed in Sri Lanka to supply electricity to the plantation sector and subsequently abandoned when grid supply came to the estates. It has been reported that out of these about 60 have been rehabilitated in recent years ${ }^{85}$. With a large number of waterways cascading from the central hills, Sri Lanka offers many sites to develop SH generation. According to an independent study, over $500 \mathrm{MW}$ of SH capacity can be generated from these streams ${ }^{86}$.

The first grid-connected SH plant was installed by a private operator in 1998. Since then a large number of sites were developed by the private sector with financial assistance provided by the GEF and the WB. The Government initially declared that only the development of mini hydro plants ( $<1 \mathrm{MW}$ ) would be financed by the private sector ${ }^{87}$, but this upper limit was subsequently extended to $10 \mathrm{MW}$. Under the RERED project, a total capacity of $117 \mathrm{MW}$ of grid-connected small and mini-hydro plants had been approved, including 35 small hydro (1.0-9.9 MW) and 11 mini-hydro plants $(200-950 \mathrm{~kW})^{88}$. As of September 2007, a total of 163 grid-connected projects with an aggregated capacity of $316 \mathrm{MW}$ were in operation or agreements signed or letters of intent issued ${ }^{89}$. Under the same project (RERED), $1,045 \mathrm{~kW}$ capacity off-grid micro-hydro systems had been completed and another $365 \mathrm{~kW}$ systems planned to provide electricity to about 5,900 households. These comprise mini-grid systems each serving a few tens of households living close to the plant. In many of these, the problem has been the inadequate capacity to meet the energy needs of the consumers, and the recurrent breakdowns and drop in the capacity during droughts ${ }^{90}$.

The impact of SH plants on the environment needs serious consideration. According to EIA guidelines of the CEA, medium hydro generation $(<50 \mathrm{MW})$ or transmission lines below $50 \mathrm{kV}$ does not need a full environment impact assessment (EIA), only an initial environment examination (IEE) is required ${ }^{91}$. Most undeveloped potential sites are in forest areas and difficult terrains. More than the land required to build the plant, building of a transmission line of many kilometres to take power to the closest substation would involve clearing of forest land causing much damage to the environment.

\section{Solar energy}

It is a misnomer to classify solar energy as an alternative source of energy, because it is the prime source of energy which maintains all living beings on earth. Even the fossil fuels have their origin to solar energy that was captured many millions years ago by vegetation which later got fossilized. The only two exceptions are the nuclear energy and geothermal energy, but these two will not be discussed here.

Solar energy insolation: Sun emits energy at a continuous rate of $3.84 \times 10^{26} \mathrm{~J}$ per second ${ }^{22}$. Solar energy incident on top of the atmosphere with the sun overhead is 1367 $\mathrm{W} / \mathrm{m}^{2}$, which is referred to as the solar constant ${ }^{93}$. The energy intercepted by the Earth is $175 \mathrm{PW}$ and the amount incident over Sri Lanka is on an average 1,170 $\mathrm{PJ} /$ day at ground level. Whereas, the total energy content in different fuels used in Sri Lanka in 2005 has been only 9,270 kTOE (Table 4) which is equivalent to $388 \mathrm{PJ} /$ year or $1.06 \mathrm{PJ} /$ day and this is only $0.09 \%$ of the solar energy incident over the country. Thus, what is required is to develop/acquire technology to harness this enormous potential available at our door step and make it the main-stream of energy source rather than consider it as an alternative source. In this context, one may attempt to simulate what is happening in nature making use of new technologies such as nano technology ${ }^{94}$.

The total radiation energy incident during a day on top of the atmosphere at different latitudes and times of the year varies from zero to $50 \mathrm{MJ} / \mathrm{m}^{2}$ because of the seasonal variation of the sun's inclination ${ }^{95}$. The maximum daily radiation is received at the South Pole during 24-hour daylight period and zero when it is in 24 hour darkness. At the equator, the solar energy incident at the top of the atmosphere varies between $33.5 \mathrm{MJ} / \mathrm{m}^{2} /$ day in 


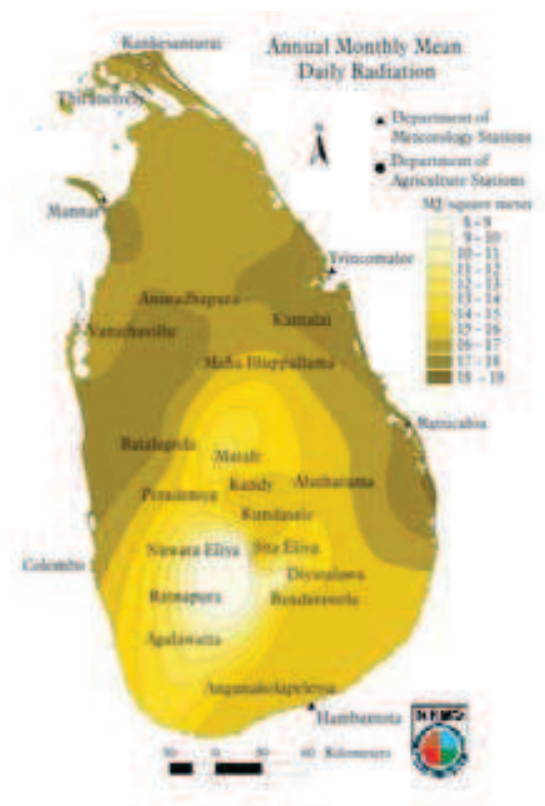

Figure 2: Distribution of monthly mean daily solar radiation over Sri Lanka

June to $35 \mathrm{MJ} / \mathrm{m}^{2} /$ day in December. The 24-hour daylight at the poles in summer makes the radiation incident there greater than that at the equator. When integrated over the year, the total energy received at the equator and poles remains within a factor of about 2 , between $13 \mathrm{GJ} / \mathrm{m}^{2}$ and $6.5 \mathrm{GJ} / \mathrm{m}^{2}$, respectively, implying that even countries at high latitudes can take advantage of solar energy.

The solar irradiance at ground level is largely dependent on the amount absorbed by various gases present in the atmosphere and the distance traversed by radiation. The energy incident on the ground at overhead sun at the equator is about $1000 \mathrm{~W} / \mathrm{m}^{2}$. This value reduces further at high solar angle due to longer path length than at overhead sun. The diurnal variation causes the intensity to have a cosine dependence which makes the 12 hour exposure during a day at the equator to be approximately equivalent to a 5-hour exposure at noon value. The absence of water vapour over deserts makes the intensity very high at these locations. The highest annual mean daily irradiance of $300 \mathrm{~W} / \mathrm{m}^{2}$ has been recorded near Red Sea area while typical value in the tropics is about $200 \mathrm{~W} / \mathrm{m}^{2}$, and the values at high latitudes about $100 \mathrm{~W} / \mathrm{m}^{2} 96$.

The irradiation falling on a few locations in Sri Lanka was measured by Samuel ${ }^{97}$ who reported annual mean values ranging from $10 \mathrm{MJ} / \mathrm{m}^{2} /$ day in the central hills to $16 \mathrm{MJ} / \mathrm{m}^{2} /$ day in the coastal belt in south and west and the dry zone in the north and east. Using these irradiance data and sun shine data, Zubair ${ }^{98}$ has constructed a solar irradiance map for Sri Lanka with greater resolution (Figue 2) where the maximum daily irradiation of $18-19 \mathrm{MJ} / \mathrm{m}^{2}$ is estimated for the eastern coastal belt and the north central province, while the minimum value of $8-9 \mathrm{MJ} / \mathrm{m}^{2}$ was estimated for the central hills.

Several technologies are available today to harness solar energy and each of these will be discussed below, both in the global and local context.

\section{Solar thermal systems}

Solar thermal (ST) systems comprise two types; flat plate (FP) collectors for individual consumer use and concentrated reflector (CR) collectors for centralised use. FP collectors are used mostly to provide hot water to dwellings and commercial buildings. The blackened plate in the collector, covered with a glass sheet and an insulation backing, absorbs the thermal energy in radiation and the resulting heat is transferred to water flowing through tubes embedded in the plate. The water line is connected in a loop to a roof-top tank. Generally water gets heated to a temperature about $60^{\circ} \mathrm{C}$ in a clear sunny day. The capacity is expressed in $\mathrm{kW}_{\text {th }}$ obtained by multiplying the effective area of the collector plate in $\mathrm{m}^{2}$ by the factor $0.7 \mathrm{~kW}_{\mathrm{th}} / \mathrm{m}^{2} 99$.

Solar thermal systems makes up more than $90 \%$ of the solar energy capacity installed worldwide, and it is one of the most cost effective forms of alternative energy sources where the investment is paid back within a matter of a few years ${ }^{100}$. ST systems are recommended to use along with gas heated systems to avoid sudden loss of heat input due to cloud cover. The global solar thermal market is dominated by China, possessing $64 \%$ of the global market of $105 \mathrm{GW}$ in 2006 . The other key players are EU (12.8\%), Turkey (6.3\%), Japan (4.7\%), and Israel (3.8\%). The breakdown of thermal installations in EU and other countries is shown in Table 19.

Table 19 Global solar water heating capacity in $2006^{101}$

\begin{tabular}{lcc}
\hline Country & Capacity (GWth) & Percentage (\%) \\
\hline China & 67.9 & 64.36 \\
EU & 13.5 & 12.80 \\
Turkey & 6.6 & 6.26 \\
Japan & 4.7 & 4.45 \\
Israel & 3.8 & 3.60 \\
Brazil & 2.2 & 2.09 \\
USA & 1.8 & 1.71 \\
Australia & 1.3 & 1.23 \\
India & 1.2 & 1.14 \\
Jordan & 0.5 & 0.47 \\
Other & 2 & 1.90 \\
World & 105.5 & 100.00 \\
\hline
\end{tabular}


In Sri Lanka, ST systems have been marketed for several decades especially for use in residences and hotels. However, the installed capacities are not included in national energy statistics and it is not possible to assess their contribution to alternative energy supply in the country. One company has claimed in its website that they have installed about 13,000 systems over a period of 23 years $^{102}$. The total capacity that has been installed amounts to $17,370 \mathrm{~m}^{2}$ or $12.16 \mathrm{MW}_{\text {th }}$. Since there are several companies involved, a rough estimate is that the total capacity installed could be in the range $30-50 \mathrm{MW}_{\text {th }}$. There is great potential to increase this share by proper marketing and some sort of incentive schemes, with a target of at least $100 \mathrm{MW}$, which has the potential to generate $0.66 \mathrm{PJ}$ annually.

In all the agro-processing industries including paddy, coconut, tea and rubber there is need to dry the products for which hot air is required. Solar thermal systems could be used for this application also. Trials carried out at the Tea Research Institute (TRI) to pre-heat air using a set of FP collectors before feeding into a furnace-heated tea drier have shown that fuel savings of $25-34 \%$ could be achieved ${ }^{103}$. Considering the fact that processing of $1 \mathrm{~kg}$ of made tea requires on an average $9 \mathrm{MJ}$ of thermal energy $^{104}$ and low country produces about $180 \mathrm{kt}$ of tea annually, introduction of solar heating in the low country could save at least $450 \mathrm{TJ}$ of thermal energy, generated either by fuel-wood or furnace oil. Many industries and hotels use fuel-fired boilers to generate steam, and much energy could be saved by getting the water that is fed to the boiler first pre-heated by solar energy.

Concentrated reflector collectors could use either a spherical parabolic dish with the collector at the focus or a cylindrical parabolic reflector (trough) with tubing at the focus carrying a thermal fluid. Generally, these have solar tracking systems for improved performance. The collector at the focus may be a simple community cooking vessel or a sophisticated heat transfer system for operating a prime mover for generating electricity. The cylindrical devices with capacities of the order of megawatts covering large extents of land are operating only as pilot scale projects. In another design, a large number - thousands - of individual mirrors (heliostats) focus radiation on to a central receiver which transfers the heat through superheated fluid to operate an engine to drive a turbine. There are already eleven such plants operating in USA with capacities in the range 14-80 $\mathrm{MW}$, adding to a total of $374 \mathrm{MW}$ and another four large plants (100-500 MW) are either under construction or development ${ }^{105}$. Six more are being planned with funding from the GEF in high insolation sites in 6 countries using troughs, dishes and mirror systems to generate electricity with capacities in the range 4-50 MW, adding to a total of $338 \mathrm{MW}^{106}$. A $100 \mathrm{MW}$ pilot scale heliostat comprising sun-tracking flat mirrors is being built in Israel $^{107}$, for later expansion to a commercial system of $900 \mathrm{MW}$ to be built in California ${ }^{108}$. This is a promising technology that Sri Lanka could adopt in view of the high insolation in certain areas.

\section{Solar photovoltaic systems}

The development of semiconductor technology has enabled the construction of photo-voltaic (PV) cells which generate an electrical direct current in a circuit connected to the cell when exposed to visible light. Panels are fabricated combining cells in different configurations to deliver various capacities of electrical power ranging from a few tens of Watts (peak) to a few hundreds of Watts (peak), which is the power generated at peak radiation intensity of $1000 \mathrm{~W} / \mathrm{m}^{2}$. At diminished light during cloud cover, current flowing and in turn the deliverable power, get reduced in proportionate to the light intensity.

According to recent studies by the Solar Energy Industries Association (SEIA) ${ }^{109}$, the US market for solar PV systems grew 20\% per year until 2006 when growth increased to $36 \%$, mainly due to the federal investment tax credit introduced in 2005. This was so in European countries as well. As a result, during the last decade, there has been a significant growth in solar PV system installations globally. The situation as at the end of 2007 is shown in Table 20, which shows the worldwide installations larger than $2.0 \mathrm{MW}_{\mathrm{p}}$.

Table 20: Global solar PV installed capacity $(>200 \mathrm{Wp})$ in $2007^{110}$

\begin{tabular}{lcc}
\hline Country & Capacity (MWp) & Percentage (\%) \\
\hline Germany & 403.7 & 46.12 \\
Spain & 245.4 & 28.04 \\
USA & 141.3 & 16.14 \\
Italy & 16.9 & 1.93 \\
Japan & 16.7 & 1.91 \\
Korea & 13.3 & 1.52 \\
Portugal & 11.8 & 1.35 \\
Netherlands & 9.0 & 1.03 \\
Switzerland & 5.1 & 0.58 \\
Belgium & 2.9 & 0.33 \\
Australia & 2.2 & 0.25 \\
Other & 7.0 & 0.80 \\
World & 875.3 & 100.00 \\
\hline
\end{tabular}

The "Other" installations are in the range $0.2-2.0$ $\mathrm{MW}_{\mathrm{p}}$ in several countries including China, Austria, Czech Republic, Philippines, Japan, India, Thailand 
and Malaysia. These are all grid-connected systems including individual residential systems of a few kilowatts capacity, which require net metering and inverters to convert the DC output into AC of appropriate voltage. Solar panels provide an opportunity for an individual to contribute to saving of GHG emissions and be a responsible citizen. The system output can be increased by providing for tracking the sun and concentrating the radiation falling on cells.

As in many other developing countries, in Sri Lanka, solar home systems (SHS) were conceived as suitable for the rural communities away from the national grid to provide essentials such as lighting and operation of a radio and black and white television. Initially nearly 21,000 SHS were installed, with a total capacity of $985 \mathrm{~kW}$ under the GEF supported ESD programme. Subsequently well over 100,000 rural homes were supplied with electricity through SHS under the RERED Projects. Some installations have been, however, abandoned after grid electricity was introduced.

Sri Lanka's National Energy Policy envisages that $6 \%$ of remote rural households will be electrified through off-grid solutions by 2010 . However, a SHS typically costs from around Rs. 35,000-60,000, an amount not affordable to most villagers. Hence, villagers had to seek credit facilities through several NGOs such as SEED of Sarvodaya, ITDG and Energy Forum to assist them. SEED has helped over 50,000 clients to purchase solar home systems through its micro-credit scheme ${ }^{111}$. During the extended financing implementation period, the project would provide energy access to 60,000 additional households in rural areas through off-grid electricity services.

In Sri Lanka, Worldview Global Media has connected a $25 \mathrm{~kW}$ solar PV system to the national grid in January 2002, making it a first-ever grid-connected solar project in the country ${ }^{112}$. According to a press advertisement which appeared recently, one of the upcoming condominium buildings is planning to install solar panels of capacity $1000 \mathrm{~W}$ to supplement the energy requirements of the building. Such initiatives taken by individual parties need to be encouraged and promoted by the Government by granting duty waivers, rebates and tax concession, enabling a wider group to undertake such projects to utilize solar energy on a larger scale than done at present. If the proposed new tariff structure was enforced, any investment on solar panels would become attractive for the affluent consuming more than 600 units a month, with pay-back period less than 5 years.

CEB statistics show that in 2006, there were about
8,900 consumers in the domestic sector consuming over 500 units monthly, and if 5,000 of them could be persuaded to get $1 \mathrm{~kW}$ panels installed, the total installed capacity would be $5 \mathrm{MW}$. Under the General category, over 500 consumers had their monthly consumption in the range $18,000-280,000$ units, and under industrial category, over 750 consumers had their monthly consumption in the range $30,000-500,000$ units $^{113}$. These heavy consumers should be given incentives - rebates, tax concessions and also national recognition - enabling at least 1000 of them persuaded to install panels of average capacity $5 \mathrm{~kW}$. This will add another 5MW capacity to the grid, making a total of $10 \mathrm{MW}$ of solar PV capacity, which has the potential to generate approximately $66 \mathrm{TJ}$ annually. The tariff applicable to these categories should be adjusted and duties and taxes waived so that investments on solar panels will have a reasonable pay back period. The levelized cost of production is immaterial in this case.

\section{Wind energy}

The steady prevailing winds at high latitudes enabled North American and European countries to exploit wind energy resources to a large extent. According to the Global Wind Energy Council, the sum of the world's total installed capacity exceeded $74 \mathrm{GW}$ by the end of 2006 . Germany is leading having $28 \%$ of the global capacity and USA and Spain following with 16\% each. Among Asian countries, India and China have jointly installed $12 \%$ of the total capacity. Table 21 shows the capacities of top 10 producers of wind power in 2006. The overall growth in 2006 has been around 32\%, while that in Asia alone has been about $53 \%$, with the main contribution coming from China. The individual plant sizes also have increased since eighties with an individual plant now having a capacity in the range 1-2 $\mathrm{MW}^{114}$.

Table 21: Installed wind power capacity among top ten countries in $2006^{115}$

\begin{tabular}{lcc}
\hline Country & Capacity (MW) & Percentage (\%) \\
\hline Germany & 20,622 & 27.8 \\
Spain & 11,615 & 15.6 \\
USA & 11,603 & 15.6 \\
India & 6,270 & 8.4 \\
Denmark & 3,136 & 4.2 \\
China & 2,604 & 3.5 \\
Italy & 2,123 & 2.9 \\
UK & 1,963 & 2.6 \\
Portugal & 1,716 & 2.3 \\
France & 1,567 & 2.1 \\
Rest & 11,005 & 14.8 \\
\hline World & 74,223 & 100.0 \\
\hline
\end{tabular}


Wind energy could also be generated using small units with capacity of a few hundreds of Watts to a few decades of kilowatts. Those below $1 \mathrm{~kW}$ are referred to as microturbines while larger units up to $100 \mathrm{~kW}$ are referred to as small turbines. Micro-turbines are generally used in off-grid applications to meet the requirements of individual consumers. Small turbines are generally gridconnected. Such systems are widely used in developed countries. For example, a total of $17.5 \mathrm{MW}$ capacity of small turbines were installed in 2006 alone in USA while another 19.5 MW of capacity were installed in 2006 outside USA ${ }^{116}$. In both cases, the majority were off-grid connected systems - 11 MW and 16.4 MW, respectively. The bulk of the installations are in the range $1-10 \mathrm{~kW}$ range. Micro-turbines of capacity $400-600 \mathrm{~W}$ are available from Indian manufacturers around US $\$ 1,000$ - 1,500 , a sum affordable to many local consumers. Ideally, a micro-turbine should be installed along with a solar PV panel to complement each other.

The wind-mapping studies performed by the US National Renewable Energy Laboratory (NREL) found that Sri Lanka has many areas estimated to have goodto-excellent wind resources, with wind power densities in the range $200-600 \mathrm{~W} / \mathrm{m}^{2}$ in the north-western and south-eastern coastal region and in north-central region, and exceeding $600 \mathrm{~W} / \mathrm{m}^{2}$ in the central highlands as shown in Figure 3. These are only indicative and further investigations from ground observations are necessary to establish the feasibility of installing WE systems at these sites.

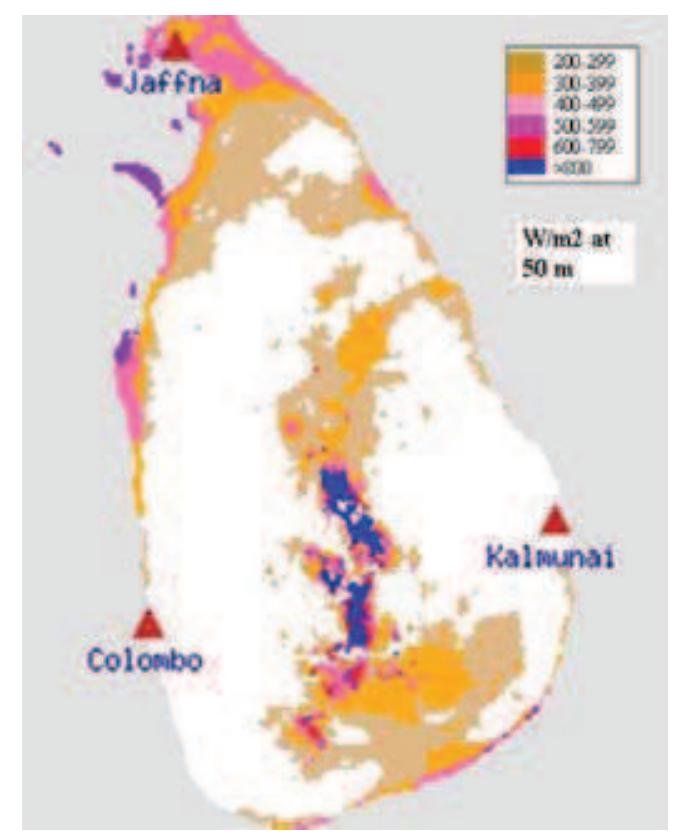

Figure 3: Wind power density assessment at $50 \mathrm{~m}$ above ground ${ }^{117}$
Based on wind data collected by CEB over a period of 3 years covering an area of $1,500 \mathrm{~km}^{2}$, a joint UNDP/WB team has assessed a total wind power potential of 1,800 MW stretching over Southern coastal belt, SE lowlands, Puttalam-Kalpitiya bay and MannarJaffna area ${ }^{118}$. The study has further revealed that as much as $2000 \mathrm{MW}$ of wind power could be absorbed gradually into the national grid over the period 2003-2018.

In Sri Lanka, a pilot scale wind power plant of capacity 3 MW consisting of 5 wind turbines of 600 kW each was commissioned in 1999 near Hambantota, financed by the WB and the GEF. The expected annual energy generation was around $4.5 \mathrm{GWh}$, with an estimated plant factor of $17 \%$. However, the plant could achieve an average plant factor of only $14 \%$ with a peak of $25 \%$ in July and a minimum of about $5 \%$ in November and $\mathrm{March}^{119}$. A proposal has been submitted to build a $50 \mathrm{MW}$ wind energy plant in Kalpitiya by an Indian Company, which is still pending ${ }^{120}$. In the meantime the construction of 3 wind energy plants each of capacity 10 MW at Kalpitiya has been approved. In Sri Lanka, small wind turbines were promoted for several decades for pumping of water and a few were installed for electricity generation too. These were installed mostly in the southern coastal area meant for individual households. There is also a $2.5 \mathrm{~kW}$ community-level plant in Hambantota area.

\section{Ocean energy}

The differential heating of the Earth between the equator and poles causes currents in the oceans and winds in the atmosphere. The interaction of winds with the sea surface causes wave movements in the water. Unlike winds, ocean current systems (OCS) are steady, flow in one direction and the flow pattern hardly changes. These currents travel from equatorial regions to polar regions in shallow waters and return to equatorial regions in deep waters carrying cold waters from the poles. As such, there is a significant temperature difference between the waters at surface and lower depths. The gravitational force of the moon causes tides in the ocean whereby the sea water level changes diurnally by several metres particularly in mid-latitudes. Exploiting these phenomena - waves, currents, temperature differences and tides - it is possible to develop systems to convert the ocean energy into usable energy forms. Sri Lanka, surrounded by the ocean, could benefit enormously, if these systems are found feasible here (except the tidal movement which is not significant here).

\section{Wave energy}

Winds carry energy, and part of this is transferred to 
water while moving on its surface creating wave motion. The size of the waves depends on the wind speed, the length of time and distance over which the wind blows and the ocean depth. The wave energy density around coastal areas in the world monitored through satellite observations ranges between about 10 to $100 \mathrm{~kW} / \mathrm{m}$ of crest length as seen in Figure 4. Any area with yearly averages of over $15 \mathrm{~kW} / \mathrm{m}$ has the potential to generate wave energy at competitive prices.

A variety of technologies are used to extract energy from waves - oscillating horizontal hinged cylinders, oscillating water columns, oscillating counterweights attached to pulleys, oscillating magnets inside solenoids and oscillating buoys. In several sites, pilot scale demonstration plants have shown the feasibility of technologies and construction of commercial plants are at various stages of development around the world. These are at Scotland, Portugal, Australia, England, Oregon, Spain and South Africa, where the wave energy density exceeds $40 \mathrm{~kW} / \mathrm{m}$ (see Fig. 4). Their capacities range from 2 to $5 \mathrm{MW}$ initially and the minimum plant factor expected is $20 \%{ }^{122,123}$, In the meantime, a firm in Israel has offered to build a $10 \mathrm{MW}$ wave energy plant in the southern coast of Sri Lanka using new technology which comprises a set of pistons creating pressure inside hydraulic oil channels driving a hydraulic motor and in turn an electrical generator ${ }^{124}$. The firm claims that the cost of electricity generated with this system is the cheapest being not more than US 2 cts. per unit ${ }^{125}$.

According to World Wave Data compiled by OCEANOR from satellite observations, the annual average wave power off the western coast of Sri Lanka is in the range $10-15 \mathrm{~kW} / \mathrm{m}$, while it is $15-20 \mathrm{~kW} / \mathrm{m}$ off the southern coast . (S. Barstow, personal communication) The estimation of wave power near the coast at specific sites needs retrieval of satellite data (available at nominal cost) and analysis and this is essential before planning any wave energy plants. Some ground studies carried out recently in Sri Lanka to identify sites along the southern coast line suitable for exploiting wave energy have concluded that at four bay sites, about $800 \mathrm{MW}$ of wave energy could be generated ${ }^{126}$

\section{Ocean Current Systems (OCS)}

Ocean current system is a complex pattern affected by the wind, water salinity and temperature, topography of the ocean floor, and the earth's rotation. These currents are driven by the temperature difference between arctic and equatorial waters; where warm waters travel near the surface towards the poles and continue at low depths carrying cold water back to the equatorial regions (see Fig. 5). These are more or less steady currents with no seasonal change. The European Commission has estimated that the OCS around the UK alone could have $4.3 \mathrm{GW}$ capacity ${ }^{127}$. When the continental shelf is narrow, OCS flow close to the shore and it is possible to install a turbine in its path to generate energy. This is similar to a WE system, but submerged. Initial studies suggest that for economic exploitation, velocities of at least $2 \mathrm{~m} / \mathrm{s}$ would be required, although it is possible to generate energy from velocities as low as $1 \mathrm{~m} / \mathrm{s}^{128}$. As shown in Fig. 12, two such shallow current systems flow past Bermuda and the Philippines and already pilot

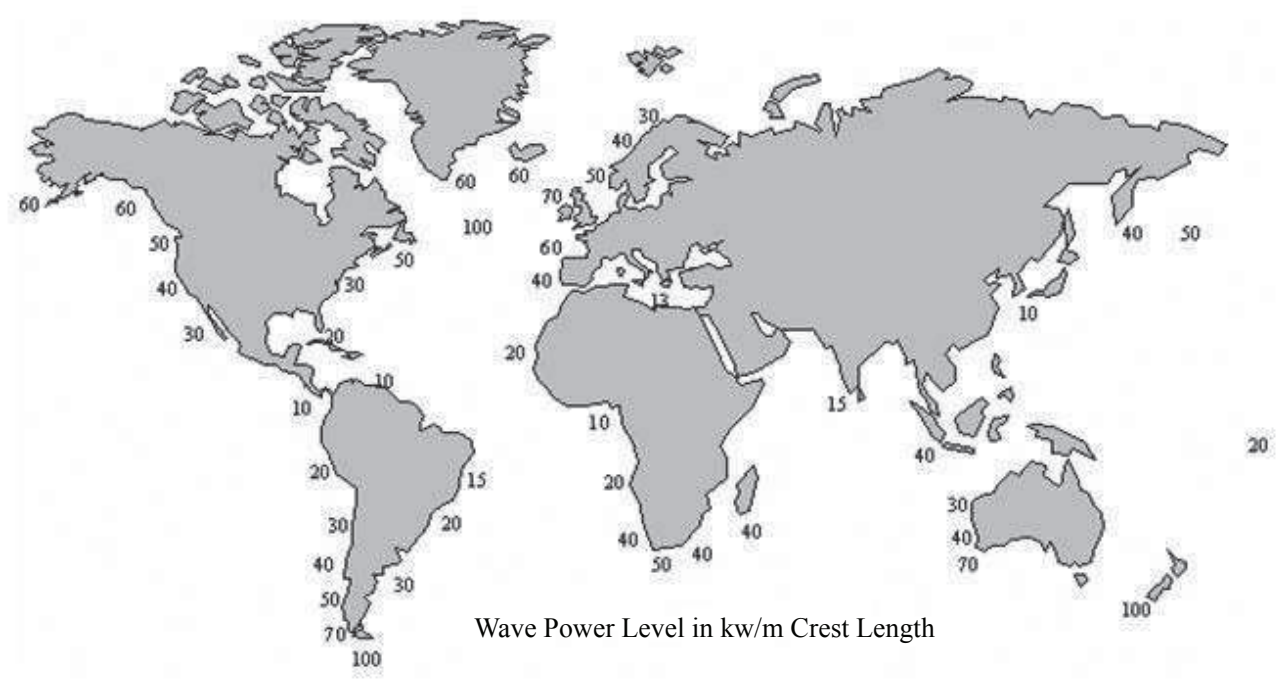

Figure 4 Wave energy density around the world in $\mathrm{kW} / \mathrm{m}$ of crest length ${ }^{121}$ 
scale projects are being planned at these two sites. In the Pacific, OCS takes the return loop from shallow to deep waters near British Columbia, where work on a $500 \mathrm{~kW}$ pre-commercial demonstration project off the coast has commenced $^{129}$.

Bermuda is planning to build a system comprising a $10 \mathrm{MW}$ submerged power plant intercepting currents in the Gulf Stream ${ }^{131}$. An ambitious project to build a 2,200 MW OCS power plant off the coast in the Philippines has been proposed by a company in British Columbia. If proven successful, this technology could be replicated in locations where suitable OCS potential exits. The shallow water warm current streams in the Pacific Ocean and the Indian Ocean take the return loop to deep waters near British Columbia and Sri Lanka, respectively, in a similar fashion. British Columbia is conducting pilot scale OCS trials off its coast, but Sri Lanka is yet to give thought to it. Unlike a wind turbine, ocean current turbine will generate energy at a steady rate and it is guaranteed. Thus, of all the alternative systems discussed, OCS has the potential to generate a steady power supply to serve the base load requirements. It is therefore worth exploring the feasibility of developing OCS to ensure energy security for the country.

\section{Ocean Thermal Energy Conversion (OTEC)}

A temperature difference existing between the surface and cold depths in the ocean could be made use of to drive a heat engine that in turn could produce electricity, desalinate water, support deep-water mariculture, and provide refrigeration and air-conditioning as well as support crop growth and mineral extraction. The temperature difference has to exceed about $20 \mathrm{oC}$ for the process to become viable. Furthermore, the site has to be within a reasonable distance form the shore and the cold water extraction point has to be within about $1000 \mathrm{~m}$ depth for the project to become practical. Equatorial regions in the Pacific and Indian Oceans offer many such locations with temperature difference in the range $20-240 C^{132}$.

Several pilot scale units have been developed over several decades but so far this technology has not been taken to commercial scale. One advantage ofOTEC system when used for electricity generation is the stability of the power output which makes it suitable for supplying base load requirements, similar to the case of OCS. Hence, many countries are pursuing this technology for which dedicated R\&D centres have been established in Hawaii and Japan. Among the few desalination plants developed is one commissioned recently on Kavaratti Island, India by the National Institute of Ocean Technology (NIOT) in Chennai ${ }^{133}$. The plant has a capacity of $100 \mathrm{kl}$ a day and NIOT has plans to build more plants. The availability of potable desalinated water as a by-product is expected to reduce the cost of electricity generated by $1 / 3$, making the projects viable. A demonstration 1.2 MW OTEC plant is now under construction at Hawaii for operation in 2009 . It is estimated that by 2020 , there could be a

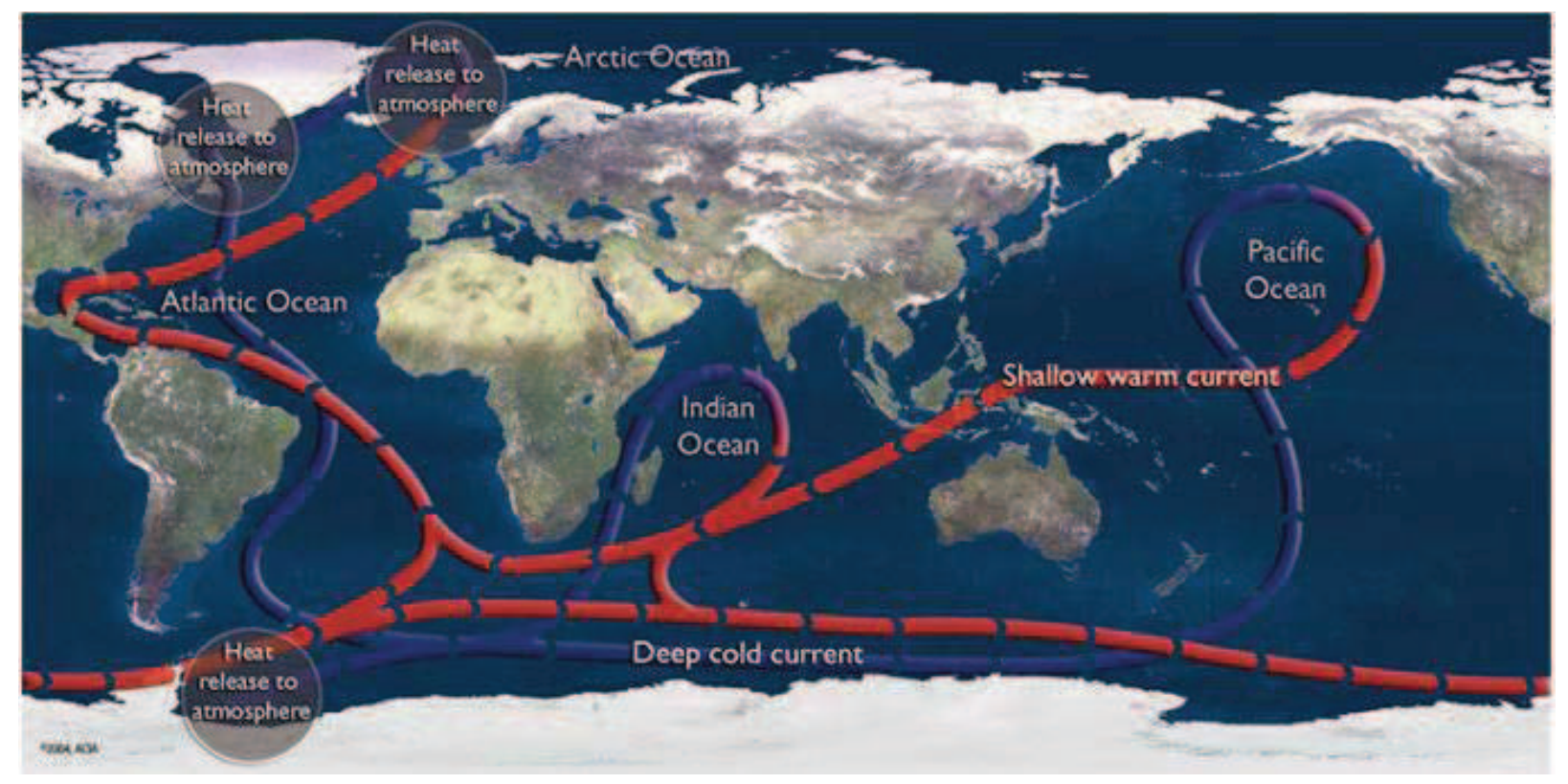

Fig. 5. Major ocean currents of the world. Red arrows indicate shallow warm currents \& blue arrows indicate deep cold currents. 
total of $20 \mathrm{GW}$ capacity OTEC plants installed in AsiaPacific region, comprising individual plants of capacity in the range 10-100 $\mathrm{MW}^{134}$.

Sri Lanka has been considering from time to time the possibility of installing an OTEC system, but the idea has been dropped due to technical and economic issues ${ }^{135}$. More recently, the National Aquatic Resources Research \& Development Agency (NARA) in collaboration with Japan's Institute of Ocean Energy at Saga University has identified three submarine canyons off the coasts at Panadura, Dondra and Trincomalee as suitable sites for OTEC plants ${ }^{136}$, and any follow up work will depend on the funding available. A separate study has shown that a series of OTEC plants each with capacity up to $5 \mathrm{MW}$ is feasible on the Eastern coast ${ }^{137}$.

\section{DISCUSSION}

\section{Hurdles for Development of Alternative Systems}

The key disincentive for the slow progress in the utilization of alternative sources is the apparent high initial cost. It is the general practice to compare the costs of different technologies by working out the costs per unit energy generated after incorporating both the initial capital cost amortised over the life time of the plant and the interest on the capital and the recurring cost which may include cost of fuel, operation and maintenance costs - both fixed and operational. Such costing referred to as levelized costs shows conventional systems such as coal, large hydro and even nuclear plants generate electricity at much cheaper rate than alternative systems ${ }^{138}$. In these analyses, only the cost of production at generation site is considered without accounting for the costs of transmission and distribution or the environmental and social costs. Electricity from a cheap coal plant has to be taken to a distant consumer for which an elaborate infrastructure is required. On the other hand, electricity from a solar panel is available at the door step with no additional costs. As such there is no level playing field in these cost calculations. What is important is the cost to the consumer and the pay-back period for investment on AES.

The lack of capacity of medium voltage substations to absorb the energy from small power plants, particularly in the up country where small hydro capacity exists, and the poor quality of the transmission network have imposed certain limitations on the grid capacity expansion ${ }^{139}$. Another barrier has been the fear that embedded generations such as grid connected small hydro-, and wind-power plants could destabilize the grid system because of their fluctuations if the total exceeds a certain minimum. According to a consultant, the limiting value of generation absorption allowable on the 2004 CEB network connected at the $33 \mathrm{kV}$ voltage level, is $140 \mathrm{MW}$ of embedded generation, which could be raised to 330 MW with the network improvements envisaged in 2008, and up to $640 \mathrm{MW}$ with network improvements due for $2013^{140}$. In these studies it has been assumed that the output of all CEB generation was reduced as the output of embedded generation was increased and suggesting that only large hydro power output be reduced as the reduction of thermal generation may seriously impede network performance. This, however, does not sound rational on two counts.

Firstly, alternative generation of energy (117 MW of small- and min-hydro plants installed by 2007 under RERED project) has been supported by GEF on grounds that such generation would avoid combustion of fossil fuel as claimed in the proposal submitted to GEF. Secondly, during 1990 - 1995, CEB had only $20 \%$ thermal capacity, with the energy generated from hydro being in the range $92.3 \%-99.8 \%$ (except in 1992 when these was a severe drought) ${ }^{141}$, and there has been no known deterioration of grid network performance solely due to this factor. One should bear in mind the objective of developing alternative sources of energy was to save on fossil fuel consumption. Hence, there is no logic in saying that mini- and small-hydro plants should be connected to the grid as embedded sources at the expense of large hydro plants and not thermal generation.

\section{Policies on Alternative Energy}

The Government has taken certain policy decisions with regard to promotion of alternative sources of energy. The National Energy Policy and Strategies adopted in 2006 has included as one policy element that indigenous energy resources will be developed to an optimum level to minimize dependence on non-indigenous resources ${ }^{142}$. The Policy has identified small-scale hydropower, biomass including dendro-power, biogas and waste, solar power and wind power as the leading NCRE sources promoted in Sri Lanka for connection into the grid. In addition, wave energy and OTEC are also encouraged where appropriate.

The Government has fixed a target of $10 \%$ of electrical energy supplied to the grid to be from NCRE sources by 2015, with interim targets for specific NCRE technologies to be included in a 20-year Long-Term NCRE Plan, which will be updated biennially, and has decided to create an Energy Fund to provide incentives for the promotion of NCRE technologies and strengthen 
the transmission network to absorb the NCRE generation. These incentives will be technology-specific, based on actual energy supplied and provided on a competitive basis. The Cabinet of Ministers has decided to declare Grilicidia as a national plantation essential for the generation of energy through fuel-wood farming by the rural poor which will enhance their economy.

The Bio Energy Association of Sri Lanka has submitted a proposal to the government several years ago outling policy elements, action plans and achievement targets for the utilization of biomass resources in Sri Lanka, suggesting the establishment of a resolving fund to promote the private sector investment on SRC plantations. In view of the many benefits, it is urged that the government take early action to implement its recommendations ${ }^{143}$.

The Government has established through an Act of the Parliament (Act 35 of 2007) a new authority - Sri Lanka Sustainable Energy Authority (SEA) - for the promotion and implement its policies and strategies in respect of NCRE sources. The Authority has already initiated to register all existing and prospective developers of renewable energy resources, and has announced a new tariff structure for purchasing electricity generated from NCRE sources ${ }^{144}$. These are technology specific with the highest for wind energy (Rs. 18.61/unit) and the lowest for wave energy (Rs. 6.82/unit) on the flat scale for the first 20 years. These appear to be on the high side compared to rates found elsewhere, and also there is no rational for the tariff to be technology-specific. Though the policy statement above refers to offering best prices for NCRE sources which has been included possibly to attract investors, supplying NCRE to the grid shall not be made an economic activity that will benefit only the investor and not the consumer.

\section{CONCLUSION}

Sri Lanka has taken the initiative many years ago to harness alternative energy resources. The availability of global funding for mitigating greenhouse gas emissions has given an impetus for the rapid penetration of alternative energy technologies to provide electrical energy both to the national grid and to villagers. The escalating prices of oil and gas have prompted establishment of energy plantations and also drawing plan for the manufacture of biofuels for transport. Both these require extensive land resources, and preliminary studies have shown the availability of about 1,000 kha for growing new energy plantations. If this land is used equitably to grow gliricidia, sweet sorghum and jatropha and using other unutilized land and sharing portions of plantation land, it is possible to replace the entire fossil fuels for electricity generation with only $1 / 6$ th of biomass utilized from these cultivations. The bioethanol produced from sweet sorghum and molasses from rehabilitated sugar plantations could also replace the entire gasoline volume that is presently consumed. Biodiesel from Jatropha in new land could replace only about $20 \%$ of diesel presently consumed. However, a more promising technology to produce biofuels is the gasification of biomass of any type to first produce syngas and then to synthesise either methanol or DME from syngas as substitutes for gasoline or diesel, respectively. With the escalation of crude oil prices, this technology will find attractive for countries which can grow sufficient amounts of biomass as well as having waste biomass.

The only two inexhaustible sources of energy available are solar and wind. Solar energy is available at our door step. With the initially proposed electricity tariff structure, installation of large solar PV panels by high-end electricity consumers is cost effective with only a short pay-back period, but with the final tariff structure, the pay back period has got extended. Government intervention is necessary to provide the necessary incentives by way of rebates, tax concessions and waiver of import duty, to encourage higher penetration, particularly among environment conscious consumers to generate their own "green" energy. Solar thermal systems should be promoted as they are cost effective for domestic, commercial and industrial use.

Even if biofuels are developed using Jatropha or sweet sorghum or gasified wood, they can only operate vehicles fitted with internal combustion engines which are polluting and only about $30 \%$ efficient. However, a new technology based on fuel cells has been developed which can operate vehicles and drive small power generators more efficiently. Fuel cell operated vehicles are already running on roads in western countries on a pilot scale and the technology will come here once commercial productions begin. There will be absolutely no pollution - only water vapour - due to exhaust emissions. Infrastructure being built currently islandwide for mandatory checking of vehicular emissions will become redundant with these vehicles.

The main obstacle with fuel cell usage is the need for hydrogen. Where natural gas is available, hydrogen could be extracted from it. Hydrogen can also be obtained simply by electrolysing water, for which a source of direct current is necessary. This can be provided either by a central concentrator type solar thermal system or by a wind energy system, both of which can be off-grid. 
Hydrogen power generation could be developed to meet the needs of both electricity generation and the transport sector. The Hydrogen generated could be distributed either by pipelines or in compressed cylinders or both. Transport of fuels could be minimized by having distributed generation system which will reduce transmission losses. Fuel cell generators could be installed at load centres such as hotels and industrial estates where the waste heat could be made use of for local requirements, thus enhancing the overall efficiently. These generators could supplement the existing hydro systems and biomass systems currently being developed.

The country has enough potential in the medium term to be self-sufficient in energy resources without depending on imported fossil fuels, provided the necessary policies and priorities are in place. Gliricidia and sweet sorghum grown in marginal land along with currently sourced biomass and agriculture residue could meet the entire energy requirement in the domestic, commercial, industrial and transport sectors except in diesel substitution. Even this could be met when technology is developed to produce DME from biomass which could replace diesel and LPG. In the long term, other alternative sources including solar, wind and ocean could be developed to produce hydrogen for use with new electrical generation and transport systems operating on fuel cell technology and to meet individual requirements.

\section{Acknowledgment}

The author wishes to thank the Editorial Board for inviting to write this article for the special issue of the Journal of the National Science Foundation Sri Lanka. He also acknowledges unpublished material provided by Mr. P.G. Joseph, Mr. I. Gallage, Mr. L. Jayasuriya and Mr. Stephen Barstow.

\section{Reference}

1. Gunatilaka A. (2006). Petroleum - depleting reserves, rising prices and the unfolding energy crisis. Journal of the National Science Foundation Sri Lanka 34(2): 61-67.

2. Energy indicators for sustainable development: guidelines and methodologies. http://www.pub.iaea. org/ MTCD /publications/PDF/Pub1222_web.pdf. Accessed in December 2007.

3. Key World Energy Statistics 2007. http://www.iea. org/textbase/nppdf/freel 2007/Key_Stats_2007.pdf. Accessed in December 2006.

4. Energy Information Administration (2007). Renewable Energy Annual 2006. Energy Information Administration, Washington, DC.
5. Renewables 2007 Global Status Report, Tables R1 \& R2.http://www.ren21.net/pdf/RE2007_Global_Status_ Report.pdf. Accessed in December 2007.

6. Climate Change Secretariat (1997). The Kyoto Protocol to the Convention on Climate Change. Climate Change Secretariat, Bonn, Germany.

7. Bali Action Plan - Decision 1 CP 13. http://unfccc. int/ files/meetings/cop_/13/application/pdf/cp_bali_ action.pdf. Accessed in December 2007.

8. Aggregate changes to GHG emissions.http://unfccc. int /files/inc/graphics/image/gif/graph2_2007_ori.gif. Accessed in January 2008.

9. Goldemberg J. (1998). The Clean Development Mechanism - Issues and Options. United $\mathrm{N}$ a t i o n s Development Programme, New York.

10. European renewable energy policy and opportunities provided by CDM. http://www.bioenergysrilanka.org / toolbox/conference_papers/european_renewable_ener gypolicy.pdf. Accessed in December 2007.

11. Climate change. http://www.gefweb.org. Accessed in December 2007.

12. Sri Lanka Sustainable Energy Authority (2007). National Energy Information System 2000, Energy Balance 2005. Sri Lanka Sustainable Energy Authority, Colombo.

13. Power generation. http://www. lankatransformers.com/ cws/view/pages/siteIndex.jsp?isFlash=tru. Accessed in December 2007.

14. Forestry Planning Unit (1995). Sri Lanka Forestry Sector Master Plan. Forestry Planning Unit, Ministry of Agriculture, Lands and Forestry, Battaramulla.

15. Energy Conservation Fund (2005). Sri Lanka Energy Balance 2003. Energy Conservation Fund, Colombo.

16. Joseph P.G. \& Jayasinghe L.P. (2007). Impending shortage of power - proposals for indigenous dolutions, Paper presented at the Annual Session of the Institution of Engineers, Sri Lanka, 2007, Colombo.

17. Fernando G.B.A., Guneratne L. \& Walpita N. (1997). National study plan on integrated rural energy planning and environment assessment. Proceedings of a Workshop held in December 1997, Colombo.

18. 2007 Renewable Energy for Rural Economic Development Project - Sri Lanka. http://www.energy services.lk/ gridconnect/esd.htm. Accessed in January 2008.

19. Renewable energy for rural economic development project- Sri Lanka. http://www.energ yservices.lk/ statistics/esd_rered.htm. Accessed in January 2008.

20. Sri Lanka Sustainable Energy Authority (2007b). Energy Data 2005, Electricity Sector. National Energy Information System, Sri Lanka Sustainable Energy Authority, Colombo.

21. Biomass conversion: emerging technologies, feedstocks and products. http://www.epa.gov /sustainability/pdfs/ Biomass\%20Conversion.pdf, Accessed in December, 2007.

22. Quaak P., Knoef H. \& Stassen H. (1999). Energy from Biomass: A review of Combustion and Gasification Technologies, The World Bank, Washington, DC. 
23. Winebrake J.J. (2003). Biomass Technology Roadmap. In: Alternate Energy Assessment and Implementation Reference Book. The Fairmount Press, Georgia, USA.

24. Perera K.K.C.K., Rathnasiri P.G. \& Sugathapala A.G.T. (2003). Sustainable biomass production for energy in Sri Lanka. Biomass and Bioenergy 25 (6): 541-556.

25. Department of Census and Statistics (2008). Statistical Abstracts 2006. Department of Census and Statistics, Colombo.

26. Somasekaram T. (1997). Land Use. In: Arjuna's Atlas of Sri Lanka. (Ed. T. Somasekaram) pp. 82-84, Arjuna Consulting Co. Ltd., Dehiwala.

27. Joseph P.G. \& Jayasinghe L.P. (2006). Local solutions for local needs. Cogeneration and On-Site Power Production Sept-Oct: 51-57.

28. Department of Census and Statistics (2006). Statistical Abstracts 2005. Department of Census and Statistics, Colombo.

29. Department of Census and Statistics (1996). Paddy Statistics 1974/75 Maha. Department of Census and Statistics, Colombo.

30. Nagenahira Navodaya Programme, Mahaweli Authority of Sri Lanka, Colombo. http://www. mahaweli.gov. lk/Other\%20pages/Nagenahira\%20Navodaya.html. Accessed in January 2008.

31. Food and Agriculture Organization (2000). Basics of Wood Energy Planning - A Manual. Regional Wood Energy Development Programme in Asia, Food and Agriculture Organization, Bangkok.

32. Ibid. 16.

33. An sssessment of the biofuels industry in India. http://www.unctad.org/en/docs/ditcted20066_en.pdf. Accessed in December 2007.

34. Feedstocks - sweet sorghum. www.iptlimited.com. au/page_var112. Accessed in December 2007.

35. FAO Statistics. faostat.fao.org. Accessed in December 2007.

36. Demirbas A. (2007). Combustion of Biomass. Energy Sources Part A 29: 549-561.

37. Renewables 2007 Global Status Report. http://www. ren21.net/pdf/RE2007_Global_Status_Report.pdf. Accessed in December 2007.

38. Bioenergy, Chapter 9 in 2007 Survey of Energy Resources. http://www.worldenergy.org/ documents/ ser 2007_final_online_version_1.pdf. Accessed in December 2007.

39. Sri Lanka Sustainable Energy Authority (2007c). Energy Data 2005, Biomass Sector. National Energy Information System, Sri Lanka Sustainable Energy Authority, Colombo.

40. Danish Energy Agency (1996). Biomass for Energy Danish Solutions. Danish Energy Agency, Ministry of Environment and Energy, Denmark.

41. Bhatacharya S.C., Attalage R.A., Leon M.A., Amur G.Q., Abdul Salam P. \& Thanawat C. (1999). Potential of biomass fuel conservation in selected Asian countries. Energy Conservation \& Management 40: 1141-1162.

42. Stove dissemination programme, Sri Lanka: an overview and assessment. http://www.fao.org/docrep x5203e/x52 03e07.htm. Accessed in March 2008.

43. Technologies promoted by Energy Forum, http:// www. energyforum.slt.lk/about_us_Technologies.htm. Accessed in January 2008.

44. Perera K.K.Y.W. (1993). An Evaluation of theTrends in the Energy Sector and Potential for Developing Renewable Energy. p.59. Sri Lanka Economic Association, Colombo.

45. Energy Conservation Fund (2005). Report of the InterMinisterial Working Committee on Dendro Thermal Technology. Energy Conservation Fund, Colombo.

46. Perera K.K.C.K., Rathnasiri P.G. \& Sugathapala A.G.T. (2003). Sustainable biomass production for energy in Sri Lanka. Biomass and Bioenergy 25(5): 541-556.

47 Perera K.K.C.K., Rathnasiri P.G., Senarath S.A.S., Sugathapala A.G.T., Bhattacharya S.C. \& Abdul Salam P. (2005). Assessment of sustainable energy potential of non-plantation biomass resources in Sri Lanka. Biomass and Bioenergy, 29:199-213.

48. The role of biomass power for sustainable development in Sri Lanka. http://217.206.197.194:8190/wecgeis/ cong ress/papers/kumaram0904ys.PDF. Accessed in January 2008.

49. E-Scene. http://www.energyforum.slt.lk/Pdf/Escene-5. pdf. Accessed in December 2007.

50. Ceylon Electricity Board (2006). Annual Report 2005. Ceylon Electricity Board, Colombo.

51. Programmes, Ministry of Science and Technology. http://www. most.gov.lk/programmes 1 php? id $=3$ Accessed in January 2008 .

52. Dendro power pilot project for electrification of 100 off-grid households. http://www.energyforum.slt.lk/. Accessed in January 2008.

53. Industry statistics. http://www.ethanolrfa.org/industry/ statistics/. Accessed in February 2008.

54. Market specifications and methods for fuel ethanol. http://www.nist.gov/oiaa/FelixSilva.pdf. Accessed in January 2008.

55. Sugarstatistics.http://www.sugarres.gov.lk/SuStatistics. htm. Accessed in January 2008.

56. Central Bank of Sri Lanka (2004). Table 1.13, Annual Report 1993. Central Bank of Sri Lanka, Colombo.

57. Karunaratne T.B. (1986). Sugar: production, consumption \& trade. Economic Review 12(7):3-18.

58. ibid 55.

59. Yield comparison between IPT sweet sorghum and alternative crops - sugarcane and maize. http://www. iptlimited.com.au/sweet_sorghum.aspx. Accessed in January 2008.

60. Sweet sorghum - food, feed, fodder and fuel crop. http://www.icrisat.orgBiopower/BVSReddyetal/ SweetSorghumBrochureJan2007.pdf. Accessed in January 2008.

61. Butanol is an alcohol that replaces gasoline. http:// www.butanol.com/. Accessed in January 2008.

62. Van Gerpen J., Shanks B., Pruszko R., Clements D. \& Knothe G. (2004). Biodiesel Production Technology, National Renewable Energy Laboratory, Colorado, USA. 
63. ibid 32. p. 22.

64. Ramadhas A. S., Jayaraj S. \& Muraleedharan C. (2005). Biodiesel production from high FFA rubber seed oil. Fuel 84(4):335-340.

65. National Biodiesel Board Website. http://www. biodiesel.org. Accessed in January 2008.

66. Biodiesel Performance, National Biodiesel Board http://www.biodiesel.org/pdf files/fuelfactsheets/ Performance.PDF. Accessed in January 2008.

67. A world wide review of the commercial croduction of biodiesel. http://itnp.mppc.at/ archiv_doc /BAND41_ FRIEDRICH.PDF. Accessed in December 2007.

68. Gasification projects, Enerfab Ltd., Colombo. http:// www.enerfabsrilanka.com $/ w w w / ? q=$ node/15. Accessed in January 2008.

69. Biomass energy technology - wood energy data 2002. http://www.rwedp.org/d_technotc.html. Accessed in January 2008.

70. Utilization of biomass energy in Sri Lanka \& Biomass Gasification. http://192.248.11.75/control /downloads/41955.34bio-mass1.pdf. Accessed in December 2007.

71. Larson E.D. \& Yang H. (2004). Dimethyl ether (DME) from coal as a household cooking fuel in China. Energy for Sustainable Development VIII: 115-126.

72. Methanol, program in forest systems \& bio-energy. http://www.cfr.washington.edu/research.Forest Energy. Accessed in January 2008.

73. An integrated biomass-derived syngas/ dimethyl ether process. http://frc.kier.re.kr/down/F2-1.pdf. Accessed in February 2008.

74. Breaking the chemical and engineering barriers to lignocellulosic biofuels: next generation hydrocarbon biorefineries. http://www.ecs. umass.edu/biofuels/ Images/Roadmap Final.pdf. Accessed in January 2008.

75. DME - The NextGen fuel. www.enzenglobal.com. Accessed in January 2008.

76. Technologies promoted by Energy Forum, http:// www.energyforum.slt.lk/about_us_Technologies.htm. Accessed in February 2008.

77. Statistics, Department of Animal Production and Health. http://www.daph.gov.lk/statistics.php. Accessed in January 2008.

78. Biomass for fuel, fodder and fertility. $w w w$. bioenergysrilanka.org/www/files/beasl/beasl agm_2008_press_release.pdf. Accessed in January 2008.

79. Statistics on Waste Management. http://www.wpc.gov. $\mathrm{lk} /$ chief-ministry-waste-04.htm. Accessed in January 2008.

80. Perera K.R.D.S. (2000). Statistical compendium on natural resources management Sri Lanka 2000, Ministry of Forestry and Environment, Battaramulla.

81. Activities of the Western Province Waste Management Authority. http://www.wpc.gov.lk/chief-ministrywaste-05.htm. Accessed in January 2008.

82. Renewable energy projects. www.mope.gov.lk. Accessed in January 2008.

83. Perera K.K.C.K., Rathnasiri P.G., Senarath S.A.S., Sugathapala A.G.T., Bhattacharya S.C. \& Abdul Salam
P. (2005). Assessment of sustainable energy potential of non-plantation biomass resources in Sri Lanka. Biomass and Bioenergy 29 (3): 199-213.

84. Hydropower, Chapter 7 in 2007 Survey of Energy Resources. http://www.worldenergy.org/documents/ ser2007_final_online_version_1.pdf. Accessed in January 2008.

85. World Energy Council (2000). Renewable Energy in South Asia - Status and Prospectus. World Energy Council and South Asian Association for Regional Cooperation, London.

86. Possibility of using small hydropower as an environmental friendly and low cost energy source. http://www.gissl.lk/water prof day/acrobatpapers/ PMPC_Gunathilake_8.pdf. Accessed in January 2008.

87. Ministry of Irrigation and Power (1998). Power Sector Policy Directions. Ministry of Irrigation and Power, Colombo

88. Renewable Energy for Rural Economic Development (RERED) Project. http://www.energyservices.lk/statistic s/disbursement.htm. Accessed in February 2008.

89. Renewable Energy Development, Ministry of Power and Energy. http://www.mope.gov.lk/uploads/project/ project en.pdf. Accessed in January 2008.

90. Use of electricity from micro-hydro projects for economic development. http://www.energyforum.slt. $l k /$. Accessed in February 2008.

91. Environment and social safeguards assessment and management framework, Sri Lanka. http://www.energy services.lk/index. htm. Accessed in January 2008.

92. Jones B. (1994). The Stars and the Interstellar Medium, The Open University, Milton Keynes, UK.

93. Tiwari G.N. (2006). Solar Energy. Narosa Publishing House, New Delhi.

94. Rajapakse R.M.G. (2006). Depletion of non-renewable energy resources, entropy crisis and nanotechnology solutions. Journal of the National Science Foundation of Sri Lanka 35(2): 59-61.

95. Campbell I.M. (1979). Energy and the Atmosphere. John Wiley \& Sons Ltd., New York.

96. Solar Energy, Chapter 7 in 2007 Survey of Energy Resources. http://www.worldenergy.org/documents /ser2007 final_online_version_1.pdf. Accessed in January 2008.

97. Samuel T. D. M. A. (1991). Estimation of global radiation for Sri Lanka. Solar Energy 47(5): 333-337

98. Zubair L. (2002). Final Report of the NRMS Component of the AIACC Project. Natural Resources Management Services, Polgolla.

99. Converting solar thermal collector area into installed capacity $\left(\mathrm{m}^{2}\right.$ to $\left.\mathrm{kW}_{\mathrm{th}}\right)$. http://www.iea-shc.org welcome/Technical20note $\% 20 \% 20$ new $\% 20$ solar $\% 20$ thermal\%20statistics\%20conversion.pdf. Accessed in January 2008.

100. Solar Thermal Action Plan for Europe. www.estif. org/ fileadmin/downloads/STAP/Solar_Thermal_Action_ Plan_2007_A4.pdf. Accessed in January 2008.

101. Renewables 2007 Global Status Report. Table R5. 
http://www.ren21.net/pdf/RE2007_ Global_Status Report.pdf. Accessed in January 2008.

102. Solar domestic water heating systems. http://www. solartherm.lk/ Soloarwater.htm. Accessed in February 2008.

103. Koneswaramoorthy S., Mohammed M.T.Z. \& Galahitiyawa G. (2004). Developing and evaluating solar energy techniques for tea drying. Journal of the National Science Foundation of Sri Lanka. 32(1\&2): 49-60.

104. de Silva W.C.A. (1994). Status review of energy utilization by the tea industry in Sri Lanka. Sri Lanka Journal of Tea Scienc. 64: 43-50.

105. CSP Plants in the US. http://www.seia.org/galleries / pdf/CSP_Plants_in_the_US_Final.pdf. Accessed in March 2008.

106. Solar thermal power in renewable energy world. http://www.volkerquaschning.de/downloads/rew2000. $p d f$. Accessed in January 2008.

107. Distributed Power Towers. http://www.brightsource energy.com/dpt.htm. Accessed in March 2008.

108. 900-MW Solar Thermal Deal. http://www.renew ableenergyworld.com/rea/news /story $\quad$ id $=52040$. Accessed in April 2008.

109. 2006 solar industry year in review: U.S. solar industry charging ahead. http://www.seia.org/Year in_Solar_2006.pdf. Accessed in March 2008.

110. Large-scale photovoltaic power plants. http://www. pvresources.com/download/AnnualReport2007.pdf. Accessed in February 2008.

111. Sarvodaya Economic Enterprise Development Services (2006). Annual Report 2005-06. SEEDS (Guarantee) Limited, Moratuwa.

112. Technologies promoted by Energy Forum. http:// www.energyforum.slt.lk/about_us_Technologies.htm. Accessed in January 2008.

113. Ceylon Electricity Board (2006). Electricity Consumption Pattern. Statistical Unit, Ceylon Electricity Board, Colombo.

114. Chapter on Wind Energy, 2007 Survey of Energy Resources. http://www.worldenergy.org/documents/ ser2007_final_online_version_1.pdf. Accessed in January 2008.

115. Global Wind 2006 Report. http://www.gwec.net/. Accessed in February 2008.

116. AWEA Small Wind Turbine Global Market Study 2007. www.awea.org/smallwind/documents/. Accessed in February 2008.

117. $50 \mathrm{~m}$ wind speed map - Sri Lanka. http://swera .unep. net/index.php?id=wind_map. Accessed in February 2008.

118. Greenhouse gas mitigation options in the Sri Lanka power sector. http://wbln0018.worldbank. org/esmap/ site.nsf / files. Accessed in February 2008.

119. 3 MW Pilot Wind Power Project. http://www.ceb.lk/ PV T/Pilot\%20Wind/semi_anu_report/anu00/project2. htm. Accessed in February 2008.

120. CEB opts to buy power at higher price, The Nation
09.09.2007. http://www.nation.lk/2007/09/09/news1. htm. Accessed in December 2007.

121. Global renewable energy resources.http://www.geni.org /globalenergy/library/renewable-energy-resources/ ocean.shtml. Accessed in February 2008.

122. Pelamis Wave Power. http://www.pelamiswave. com/ index.php. Accessed in March 2008.

123. Knot M. (2003) Power from the waves. New Scientist 179 (2413): 33-35.

124. Hills L. (2008) Sea-wave power plant soon in Sri Lanka, Sunday Times 23.03.2008, Colombo 02.

125. 2006 Directory: S.D.E. EnergyLtd. http://peswiki.com/ index.php/Directory:S.D.E._Energy_Ltd. Accessed in February 2008.

126. Soyza A. \& Tennekon T.K.D (2004). Investigation of Possible Ocean Wave Energy Harnessing Sites - Interim Report. Open University of Sri Lanka, Nugegoda.

127. Marine Current Technology. http://www.euoea.com/ index. asp? bid = 232\#Marine\%20Current. Accessed in February 2008.

128. Technology white paper on ocean current energy potential on the U.S. outer continental shelf. http:// ocsenergy.anl.gov. Accessed in February 2008.

129. Tidal Energy. http://www.bcsea.org/sustainableenergy/ ti dal.asp. Accessed in February 2008.

130. World Wide Development of Ocean Energy. http:// www.oceanenergycouncil.com/development.html. Accessed in February 2008.

131. Report on arctic climate impact assessment. http:// www.amap.no/acia/. Accessed in February 2008.

132. Ocean thermal energy conversion. http://www.nrel. gov/otec/design_location.html\#shelf. Accessed in February 2008.

133. Desalination plant handed over to Lakshadeep Administration. http://dst.gov.in/whats_new/press release06/lakshadeep -admin.htm, Accessed in February 2008.

134. Chapter 15 on Ocean Thermal Energy Conversion, 2007 Survey of Energy Resources. org /documents / ser2007_final_online_version_1.pdf. Accessed in January 2008.

135. ibid 44, p. 19.

136. Ibid 134. p. 579.

137. Potential of ocean thermal energy conversion for Sri Lanka. http://www.ncpcsrilanka.org Roundtabl e\%20 Web/Papers/T3_9.pdf. Accessed in February 2008.

138. Asia Pacific Energy Research Centre, Institute of Energy Economics (2005). Renewable Electricity in the APEC Region - Internalising Externalities in the Cost of Power Generation. APERC, Japan.

139. Department of Planning (2007). Mahinda Chintanaya - Vision for a New Sri Lanka, A ten year horizon development framework 2006-2016. p. 69. Department of Planning, Ministry of Planning, Colombo.

140. Technical assessment of the generation absorption capacity of the Sri Lanka Power System. http:// www.energyservices.lk/pdf/finalreport_04_08_05p.pdf. Accessed in February 2008. 
141. Ceylon Electricity Board(1999). Long Term Generation Expansion Plan 1999-2013. Ceylon Electricity Board, Colombo.

142. Ministry of Power and Energy (2006). The National Energy Policy and Strategies of Sri Lanka. Ministry of Power and Energy, Colombo.
143. The dendro option for future energy security of Sri Lanka. http://www.nsf.ac.lk/beasl/download/Dendr o-Policy-document.pdf. Accessed in February 2008.

144. Anonymous (2008). NCRE Tariff Announcements 2008. Daily News, 18.03. 2008, p. 23, Colombo. 